\title{
Revisão do gênero Physopleurus Lacordaire, 1869 e notas em Macrotomini (Coleoptera, Cerambycidae, Prioninae)
}

\author{
Antonio Santos-Silva ${ }^{1}$ \\ Ubirajara R. Martins ${ }^{1,2}$
}

\begin{abstract}
Revision of the genus Physopleurus Lacordaire, 1869 and notes on Macrotomini (Coleoptera, Cerambycidae, Prioninae). The genus Physopleurus Lacordaire, 1869 = Basitoxus (Parabasitoxus) Fragoso \& Monné, 1995 syn. nov. is revised and redefined based on new characters. The following species are treated (in sequence that appear in the presented key): Physopleurus exiguus sp. nov. (Bolivia and Brazil), P. crassidens (Bates, 1869), P. longiscapus Lameere, 1912, P. rugosus (Gahan, 1894), P. tritomicros Lameere, 1912, P. seripierriae sp. nov. (Brazil, Mato Grosso), P. dohrnii Lacordaire, 1869, P. villardi (Lameere, 1902) = Aplagiognathus guatemalensis Casey, 1912 syn. nov., P. amazonicus (Fragoso \& Monné, 1995) comb. nov., and. P. maillei (Audinet-Serville, 1832) comb. nov. The latter two species formerly in Basitoxus (Parabasitoxus) Fragoso \& Monné, 1995. Illustrations of Basitoxus megacephalus (Germar, 1824) are included to allow comparisons with Physopleurus species. Key to species of Physopleurus is added.
\end{abstract}

Keywords. Basitoxus; Cerambycidae; Macrotomini; Physopleurus; taxonomy.

\section{INTRODUÇÃO}

LACORDAIRE (1869: 56), na chave para grupos, alocou os "Remphanides", que incluia Physopleurus Lacordaire, $1869 \mathrm{e}$ Basitoxus Audinet-Serville, 1832, a partir do dilema "hh": "Languette petite, entière ou faiblement sinuée en avant" e confirmou na descrição (l. c.: 103): "Languette petite, entière en avant"... "C'est de tous les groupes de Prionides, celui don't l'arrangement systématique présente le plus de difficulté, même en laissant de côté les femelles". Lacordaire (op. cit.: 120) erigiu Physopleurus para P. dohrnii Lacordaire, 1869 e comentou ao comparar Basitoxus e Physopelurus: "Si l'on découvre des passages, celui-ci devra alors être supprimé".

LAMEERE (1902) colocou Physopleurus como subgênero de Stenodontes Audinet-Serville, 1832, e escreveu na redescrição genérica: "languette petite, entière". LAMEERE (1903) na redescrição do subgênero Basitoxus, afirmou: "la languette assez grande et bilobée". LAMEERE (1919), entre os caracteres distintivos do subgrupo "Basitoxi" (que incluia Basitoxus), afirmou: "languette grande et bilobée" e para o subgrupo "Stenodontes" (que incluia Physopleurus): "languette petite et ordinairement entière". LAMEere (1912) elevou Physopleurus a gênero: "Ces Insectes ont le bord antérieur de la languette prolongé de chaque côté en un lobe triangulaire, de sorte qu'il y a lieu d'en faire un genre distinct des Stenodontes". Embora
Physopleurus realmente seja um gênero distinto de Mallodon (= Stenodontes, parte), esse gênero também possui os ápices das paraglossas aguçados, mas a lígula em todas as espécies de Mallodon examinadas é bem menor, além de apresentar outros caracteres distintivos.

Fragoso \& Monné (1995b) criaram o subgênero Basitoxus (Parabasitoxus) para B. (Parabasitoxus) maillei AudinetServille, 1832 e B. (Parabasitoxus) amazonicus Fragoso \& Monné, 1995. Como caracteres do subgênero, relacionaram: “... dimorphism is utterly remarkable on the prosternum, which is widened and bulged, to the point of being visible dorsally [laterad of the crenulated border]; the proepisterna are null as an area. The females of both species have a distinct prosternal suture, subparallel to pronotal border, defining, at each side, a glabrous, subplicate, unpunctate, relatively broad episternal area (each about one-eighth of proventral surface)". Tais caracteres encontram-se em Physopleurus e, portanto, Basitoxus (Parabasitoxus) é considerado sinônimo.

Fragoso \& MonNé $(l . c$. ) comentaram e atribuiram importância à presença ou não de espinhos nas tíbias para separar Basitoxus s. str. de B. (Parabasitoxus): "The presence or absence of spines in the legs has been formely used to differentiate genera among macrotomines". No entanto, este caráter varia nas espécies de Physopleurus e não é útil para definir o gênero. Espécies com morfologia externa muito

1. Museu de Zoologia, Universidade de São Paulo. Caixa Postal 42649, 04299-970 São Paulo-SP, Brasil.

2. Pesquisador do CNPq. 
semelhante (e.g. P. amazonicus e P. dohrnii), apresentam ou não espinhos nas tíbias. Os autores também escreveram: "Physopleurus, placed in another group ("Stenodontes") of equal rank to "Basitoxi", is apparently distinct [by several other characters found in literature] from Basitoxus, but quite closely related to it".

Pelo exposto, vê-se que desde a criação de Physopleurus, houve dúvidas relacionadas à delimitação entre esse gênero $\mathrm{e}$ Basitoxus Audinet-Serville, 1832. É importante observar que os caracteres utilizados para diferenciá-los são variáveis, principalmente a forma e tamanho da lígula. O estudo de todas as espécies de Physopleurus (exceto P. dohrnii, examinada apenas por fotografias e diapositivos) e de Basitoxus megacephalus (espécie-tipo) mostrou que a lígula realmente é diferente nos dois gêneros, mas não da forma como aceita atualmente (vide discussão sob o gênero Physopleurus). O exame do holótipo de Physopleurus amazonicus (Fragoso \& Monné, 1995), mostra que a lígula não é bilobada, apesar de constar na redescrição do gênero Basitoxus: "ligula bilobed, each lobe large, subtriangular". Os demais exemplares examinados de P. amazonicus apresentam a borda anterior da lígula desde aguçada até fracamente bilobada.

O reduzido número de exemplares disponível para as descrições e redescrições das espécies fez com que, provavelmente, fosse desconsiderada a variação da forma da lígula.

Os limites de Physopleurus, considerados por LACORDAIRE (l. c.), devem ser ampliados. O principal caráter utilizado por LACORDAIRE $(l . c$. ) - prosterno fortemente intumescido - não é comum a todas as espécies, mas a semelhança de caracteres morfológicos (principalmente externos) observada entre elas (e.g. P. rugosus e P. longiscapus) não permite erigir novo gênero ou mesmo dividi-lo em subgêneros.

Neste trabalho, as citações bibliográficas são restritas à descrição original e ao catálogo de MonNÉ (1995) mas, quando pertinente, outras citações são acrescidas.

A terminologia utilizada para a morfologia externa da cabeça segue Gahan (1906). A ordem das espécies no texto segue a de saída na chave.

As siglas mencionadas correspondem às seguintes instituições: BMNH, The Natural History Museum, Londres; DZUP, Departamento de Zoologia, Universidade Federal do Paraná, Curitiba; ISNB, Institut Royal des Sciences Naturelles de Belgique, Bruxelas; MCNZ, Museu de Ciências Naturais, Fundação Zoobotânica do Rio Grande do Sul, Porto Alegre; MNHN, Muséum National d'Histoire Naturelle, Paris; MNRJ, Museu Nacional, Universidade Federal do Rio de Janeiro, Rio de Janeiro; MZSP, Museu de Zoologia, Universidade de São Paulo, São Paulo; NHRS, Naturhistoriska Riksmuseet, Estocolmo; USNM, National Museum of Natural History, Washington; ZMHB, Museum für Naturkunde der HumboldtUniversität, Berlin; ZMPA, Museum of the Institute of Zoology, Polish Academy of Science, Varsóvia; ZMUH, Zoologisches Institut und Zoologisches Museum, Universität von Hamburg, Hamburgo.

\section{Physopleurus Lacordaire, 1869}

Physopleurus Lacordaire, 1869: 120; Lameere,1912: 126; 1913: 14 (cat.); 1919: 34; Blackwelder, 1946: 553 (cat.); Zajciw, 1960: 69; Rosales, 1966: 100; Monné \& Giesbert, 1994: 6 (cat.); Monné, 1995:14 (cat.).

Espécie-tipo: Physopleurus dohrnii Lacordaire, 1869, monotipia. Stenodontes (Physopleurus); Lameere, 1902: 86; 1903: 214. Basitoxus (Parabasitoxus) Fragoso \& Monné, 1995b: 721. Syn. nov. Espécie-tipo: Basitoxus maillei Audinet-Serville, 1832.

Macho. Tegumento em diversos tons de castanho, monocromáticos ou com mais de um matiz. Corpo longo e largo (Fig. 23). Cabeça (Fig. 30) larga; região dorsal fortemente pontuada. Suturas frontais e coronal nítidas em toda extensão ou parcialmente. Sutura epistomal ausente. Ápice dos tubérculos anteníferos aguçados, truncados ou emarginados, mas sempre sub-horizontais e dirigidos para trás. Base do labro coplanar com a borda do anteclípeo. Borda anterior do anteclípeo côncava ou sub-reta. Submento elevado ou subplano. Mento (Figs. 25,33) fortemente transverso. Ápice das genas variável. Gula pontuada. Olhos mais longos que largos; lobos oculares superiores mais afastados que o dobro da largura de um lobo. Lígula (Figs. 20, 36, 52, 61, 81, 97, 113) variável: nitidamente bilobada ou inteira; região central fortemente côncava, com aspecto de "V" em vista frontal; paraglossas com ápice aguçado. Artículos dos palpos maxilares alongados; segundo artículo em geral mais longo do que o terceiro. Mandíbulas (Figs. 22, 39, 55, 65, 84, 101, 117) arqueadas, variáveis em forma, escultura e pilosidade; dentes da margem interna variáveis em quantidade e posição; margem láteroexterna arredondada e com reentrância acentuada na base. Antenas mais curtas que o corpo; antenômeros, principalmente I-IV, variáveis em comprimento e largura. Protórax transversal, com ângulos anteriores salientes. Pronoto com margens laterais sublisas, crenadas ou fracamente espinhosas; lados nitidamente pontuados; disco com áreas lisas e brilhantes; ângulos posteriores marcados ou não; margem lateral com espinho (angulosidade lateral) próximo aos ângulos posteriores (apenas indicado em algumas espécies). Prosterno notavelmente intumescido ou apenas convexo. Suturas prosternais (Figs. 21, $37,54)$ presentes ou não; quando presentes, sempre convergem em direção ao pronoto a partir das cavidades coxais. Esternos torácicos pubescentes. Élitros glabros; pontuação variável: microscópica, fina ou grossa; ápices elitrais inermes ou espinhosos. Urosternitos brilhantes, com pilosidade esparsa, exceto o último que, em geral, apresenta pilosidade conspícua nas margens e na área centro-apical. Fêmures e tíbias inermes ou espinhosos.

Fêmea. Mandíbulas (Figs. 27, 40, 56, 64, 71) e antenas subiguais às dos machos, mas sempre mais curtas. Prosterno nunca fortemente intumescido. Proepisternos sempre nítidos.

Discussão. Physopleurus é semelhante a Basitoxus, mas difere: corpo mais largo (Fig. 46); cabeça (Fig. 30) geralmente maior e mais larga; mento (Fig. 33) mais longo e mais estreito; ápice dos tubérculos anteníferos salientes; ápice das 
paraglossas (Fig. 81) aguçado; lígula menor e fortemente côncava; artículo II dos palpos maxilares, em geral, mais longo do que o III; gálea (Fig. 49) geralmente não atinge o ápice do artículo II dos palpos; ângulo lateral do protórax (Figs. 30, 31) com espinho, em geral, mais curto; suturas prosternais (Figs. 53, 54, 62,63), quando presentes, curvas. Em Basitoxus o corpo e a cabeça (Fig. 1) são mais estreitos; mento (Fig. 2) mais curto e largo; ápice dos tubérculos anteníferos não-saliente; ápice das paraglossas (Figs. 4-6) arredondado; lígula maior e subplana; artículo II dos palpos maxilares mais curto ou subigual ao III; gálea (Fig. 3) atinge ou ultrapassa o ápice do artículo II dos palpos; ângulo lateral do protórax (Fig. 1) com espinho mais longo; suturas prosternais (Figs. 7,8 ) retas. As mandíbulas (Figs. 9, 10) em Basitoxus são semelhantes às de algumas espécies de Physopleurus (e.g. P. amazonicus) mas, em geral, apresentam a carena dorsal inconspícua ou fortemente alargada.

O lobo médio (Figs. 41 - 43, 86 - 88, 104 - 106), nas espécies de Physopleurus em que o edeago foi extraído (P. amazonicus, P. maillei, $P$. longiscapus, $P$. villardi), é nitidamente arqueado em vista lateral, o tégmen geralmente não é fortemente arqueado em vista lateral (Figs. 44, 90, 103) e os braços da peça-anelar (Figs. 45, 89, 102) não são fortemente curvados. Em Basitoxus, o lobo-médio (Figs. 11 - 13) é sub-reto, o tégmen é fortemente arqueado em vista lateral (Fig. 14) e os braços da peça-anelar (Fig. 15) são curvos.

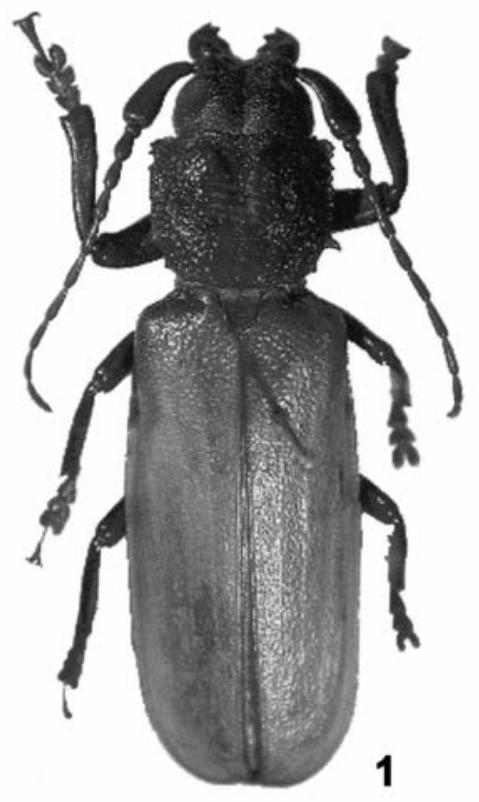

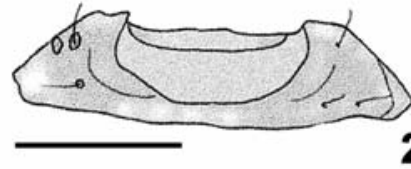

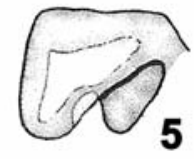

2
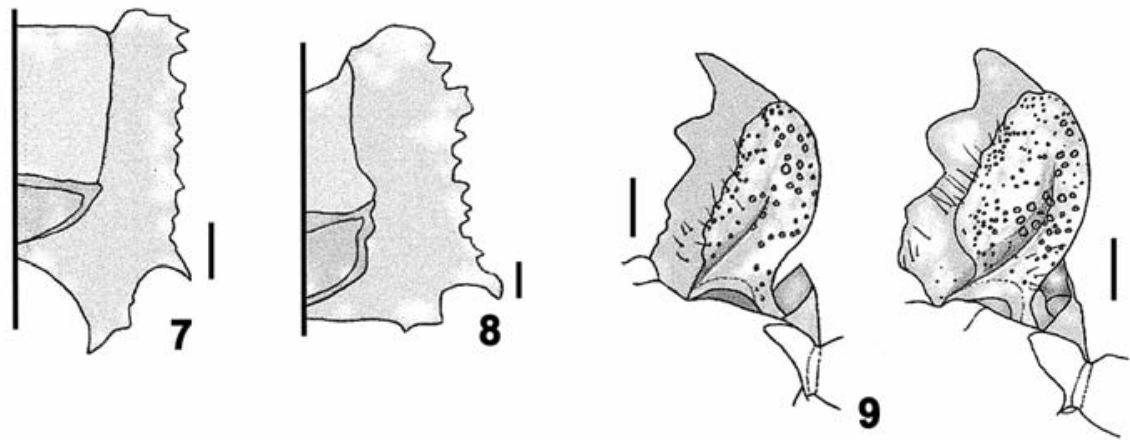

10
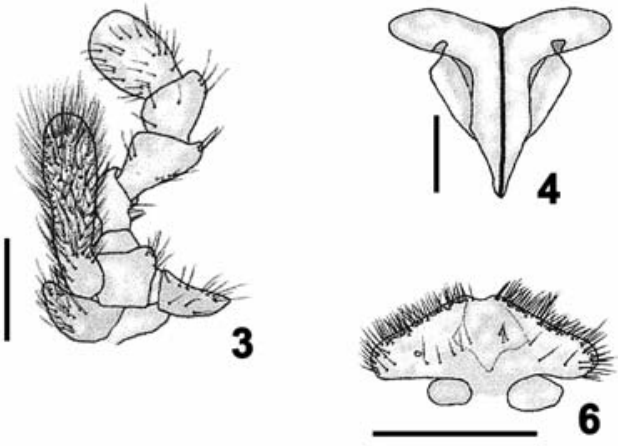
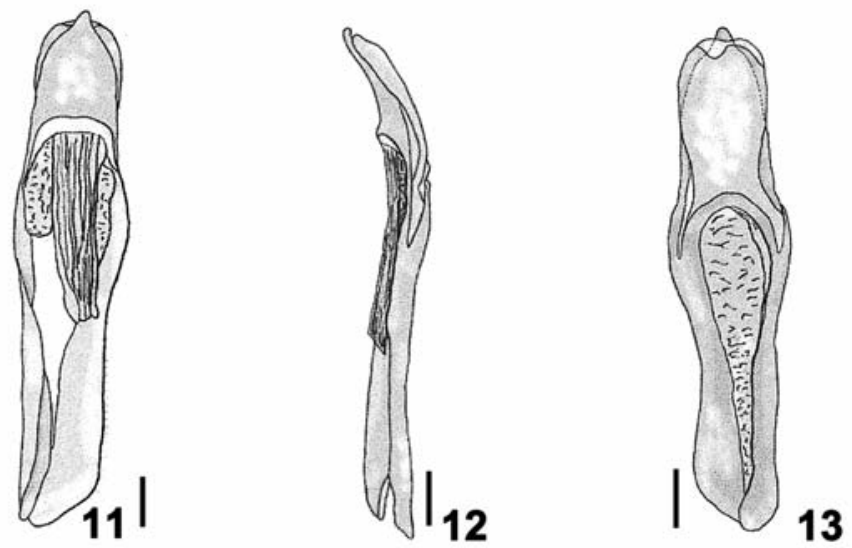

Figs. 1-15. Basitoxus megacephalus (Germar, 1824). 1, macho, comprimento, 50,0 mm; 2, mento; 3, maxila; 4-6, lígula: 4, face interna; 5, lateral; 6, face externa; 7-8, protórax, ventral: 7, macho; 8, fêmea; 9-10, mandíbula direita: 9, fêmea; 10, macho; 11-13, lobo médio: 11, ventral; 12, lateral; 13, dorsal; 14-15, tégmen: 14, lateral; 15; dorsal. Barra $=1 \mathrm{~mm}$. 
Physopleurus difere de Mallodonhoplus Thomson, 1860, que também apresenta o prosterno fortemente intumescido, pelos tubérculos anteníferos sub-horizontais e pela margem látero-externa das mandíbulas arredondada. Em Mallodonhoplus os tubérculos anteníferos são nitidamente eretos e a margem látero-externa das mandíbulas é sub-reta.

A lígula em Physopleurus é variável tanto intra- quanto interespecificamente. A variação, na mesma espécie, não está associada à distribuição geográfica, sexo ou tamanho do espécime.

Basitoxus (Parabasitoxus) Fragoso \& Monné, 1995, possui caracteres distintivos incluídos entre os de Physopleurus e, portanto, deve passar à sinonímia.

Distribuição (Fig. 123). Américas Central e do Sul.

Chave para as espécies de Physopleurus

1. Protíbias com espinhos .2

Protíbias inermes . .8

2(1). Mandíbulas dos machos fortemente salientes na margem externa (Figs. 22, 23); margem interna com dentes na metade apical que, em conjunto, têm aspecto de placa; mandíbulas das fêmeas (Figs. 24) subiguais ou mais curtas que o escapo

Mandíbulas dos machos não ou apenas salientes na margem externa (Figs. 39, 65); dentes da margem interna separados; mandíbulas das fêmeas (Figs. 47, 58) mais longas que o escapo (se a mandíbula for subigual ao escapo em comprimento, os élitros são grossamente pontuados)

3(2). Lados do prosterno dos machos visíveis em vista dorsal; escapo aproximadamente com o dobro do comprimento do antenômero III. BOLÍVIA (Santa Cruz); BRASIL (Mato Grosso) ....... P. exiguus sp. nov.

Lados do prosterno dos machos invisíveis em vista dorsal; escapo aproximadamente $1 / 3$ mais longo que o antenômero III. BRASIL (Amazonas, Mato Grosso) P. crassidens (Bates, 1869)

4(2). Élitros com pontuação grossa (Figs. 30, 31, 46, 47) ........ 5 Élitros com pontuação fina (Figs. 24, 107, 108)

5(4). Escapo dos machos ultrapassa a borda posterior do olho (Fig. 30) em aproximadamente $1 / 2$ do seu comprimento e, nas fêmeas, apenas atinge (Fig. 31); ângulo sutural dos élitros com espinho. COLÔMBIA (Putumayo); EQUADOR (Napo); PERU (Loreto); BRASIL (Amazonas, Pará, Mato Grosso)

P. longiscapus Lameere, 1912

Escapo dos machos apenas atinge a borda posterior do olho (Fig. 46) e, nas fêmeas (Fig. 47), não atinge; ângulo sutural dos élitros apenas saliente. GUIANA FRANCESA; BRASIL (Amapá, Amazonas, Pará)
P. rugosus (Gahan, 1894)

6(4). Antenômero III com aproximadamente $1 / 4$ do comprimento do escapo; élitros com carenas nítidas. GUIANA FRANCESA .................... P. tritomicros Lameere, 1912

Antenômero III com aproximadamente metade do comprimento dos escapo; élitros sem carenas ou com carenas inconspícuas

7

7(6). Élitros amarelo-alaranjados, nitidamente contrastantes com o restante do corpo; todas as tíbias fortemente espinhosas. BRASIL (Mato Grosso)

P. seripierriae sp. nov.

Élitros castanhos, não-contrastantes com o restante do corpo; meso- e metatíbas fracamente espinhosas ou inermes. VENEZUELA ........ P. dohrnii Lacordaire, 1869

8(1). Antenas atingem o terço basal dos élitros; ângulos posteriores do protórax salientes (geralmente em espinho); carena dorsal das mandíbulas estreita. GUATEMALA (Escuintla); EQUADOR (Guayas); PERU ……………………..... P. villardi (Lameere, 1902)

Antenas atingem, no máximo, o quarto basal dos élitros; ângulos posteriores do protórax nulos ou obtusos; carena dorsal das mandíbulas larga 9

9(8). Escapo não ultrapassa a borda posterior do olho; arco formado pelo prosterno dos machos (Fig. 98), entre as cavidades coxais e o pronoto, geralmente ultrapassa o nível do ângulo lateral do protórax e sua base interna é quase perpendicular em relação ao ângulo das cavidades coxais; nas fêmeas, o arco forma ângulo sub-reto (Fig. 99). PERU (Huanuco); BRASIL (Amapá, Amazonas, Pará, Mato Grosso)

. P. amazonicus (Fragoso \& Monné, 1995)

Escapo dos machos ultrapassa a borda posterior do olho e, nas fêmeas, apenas atinge; arco formado pelo prosterno dos machos (Fig. 115), entre as cavidades coxais e o pronoto, geralmente não ultrapassa o nível dos ângulos laterais do protórax e sua base interna é obliqua em relação ao ângulo das cavidades coxais; nas fêmeas, $o$ arco forma ângulo fortemente obtuso (Fig. 114). BRASIL (Alagoas, Espírito Santo, Rio de Janeiro, São Paulo, Santa Catarina); PARAGUAI; ARGENTINA (Tucumán, Misiones)

P. maillei (Audinet-Serville, 1832)

\section{Physopleurus exiguus sp. nov.}

(Figs. 17-22)

Etimologia. Latim, exiguus $=$ pequeno. Relativo às dimensões do holótipo.

Macho (Fig. 17). Tegumento castanho-escuro; cabeça, escapo, protórax e tíbias mais escuros.

Fronte com pontuação grossa, profunda e anastomosada. 
Área posterior dos olhos opaca; escultura passa gradualmente de pontuada a rugosa. Clípeo deprimido; escultura de pontos rasos, grossos e confluentes; pilosidade curta e muito esparsa. Sutura coronal distinta. Suturas frontais apenas indicadas. Área do anteclípeo com pêlos longos moderadamente concentrados. Labro com pontos esparsos; pilosidade longa e cerrada; ápice arredondado. Ápice das genas projetado e aguçado. Mento (Fig. 18) aproximadamente 5 vezes mais largo que longo. Submento gradualmente elevado e com pontuação fina. Gula deprimida. Lígula inteira. Distância entre os ápices das paraglossas (Fig. 20) cerca de 7 vezes menor do que a largura da cabeça (Fig. 16). Segundo artículo dos palpos maxilares (Fig. 19) mais longo do que o terceiro. Mandíbulas (Fig. 22) com carena dorsal elevada, que termina próximo ao terço apical; margem interna com pêlos longos e três dentes: dois dentes juntamente protraídos na metade apical, o primeiro subtriangular e o segundo largamente truncado e com borda sinuosa (esses dentes formam uma placa destacada e fortemente obliqua); terceiro dente triangular, aproximadamente no meio, em nível mais elevado do que o ápice do dente anterior; margem lateral externa fortemente intumescida no meio. Antenas atingem o meio dos élitros; escapo ultrapassa a borda posterior do olho, cerradamente pontuado; antenômero III com cerca de metade do comprimento do escapo; antenômeros III-IV subiguais em comprimento.

Protórax com comprimento, no centro, cerca de 0,6 vezes a maior largura; bordas laterais fracamente crenadas. Borda anterior do pronoto côncava; cantos anteriores em ângulo agudo, pouco projetados; ângulos das bordas laterais salientes, não-espinhosos; ângulos posteriores nulos; disco pronotal com calosidades brilhantes e pontos pequenos, esparsos; laterais com pontos grandes anastomosados. Prosterno intumescido, glabro, com pontos grossos e profundos, a maioria não-confluente. Ápice do processo prosternal saliente, liso e arredondado. Suturas prosternais (Fig. 21) distintas apenas próximo aos ângulos anteriores do protórax. Limites entre o prosterno e os proepimeros distintos apenas pela diferença na escultura (proepimeros rugosos). Proepisternos (Fig. 21) nulos. Metasterno liso e brilhante no centro; laterais e região anterior com pontos finos entremeados por pontos grossos e profundos e pilosidade curta, abundante. Metepisternos com microasperezas e pilosidade igual à do metasterno. Élitros fina e abundantemente pontuados; ápices elitrais com espinho curto. Asas translúcidas. Fêmures com pilosidade esparsa no lado ventral; borda ínfero-distal com espinhos pequenos. Tíbias fortemente pontuadas e com pilosidade nítida no lado interno (principalmente as protíbias); protíbias com um ou mais espinhos na face externa; mesotíbias inermes ou com raros espinhos; metatíbias inermes; esporão apical externo das protíbias moderadamente curto, voltado para baixo.

Fêmea. Margem lateral externa das mandíbulas, não ou fracamente intumescida no meio; dentes da margem interna menores e menos projetados. Antenas atingem o quarto basal dos élitros. Prosterno com pontos mais esparsos e rasos. Sutura prostenal marcada. Proepisternos estreitos.

Dimensões, em mm (macho / fêmea). Comprimento total, 37,8-45,0 / 28,9-46,7; protórax: largura anterior, 7,0-8,7 / 5,3-8,3; largura entre os espinhos dos ângulos das margens laterais, 9,2-10,1 / 7,4-11,2; comprimento do pronoto (centro), 5,3-6,8 / 4,4-6,8; largura umeral, 10,3-12,0/5,8-12,6; comprimento elitral, 23,6-28,3/21,1-31,5.

Material-tipo. Holótipo macho. BRASIL, Mato Grosso: Rosário Oeste, X.1972, sem nome do coletor (MNRJ). Parátipos: BOLÍVIA. Santa Cruz: 4-6 km SSE Buena Vista (Hotel Fauna \& Flora), macho, 14-

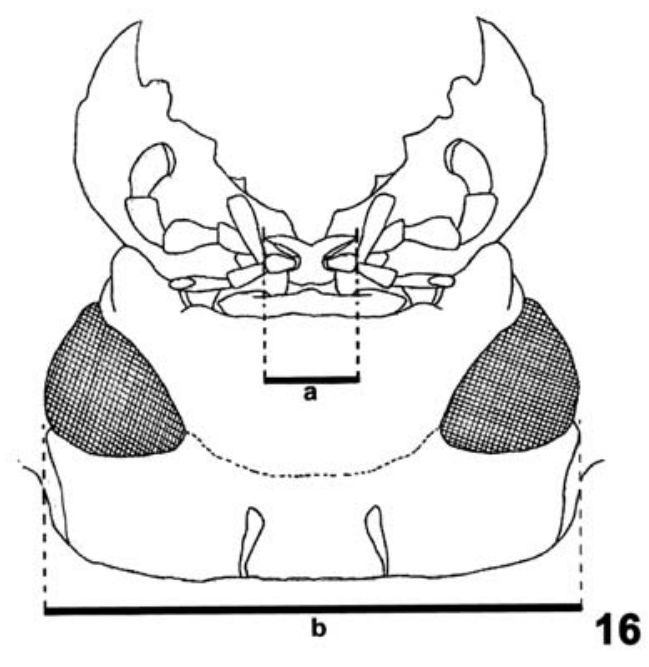

Figs. 16-22. 16, Physopleurus sp., cabeça, ventral: a, distância entre os ápices das paraglossas; b, largura da cabeça, atrás dos olhos. 17-22. Physopleurus exiguus sp. nov., holótipo macho, comprimento, $37,8 \mathrm{~mm} ; \mathbf{1 8}$, mento; 19, palpo maxilar; 20, lígula, face externa; 21, protórax, ventral; 22, mandíbula direita. Barra $=1 \mathrm{~mm}$.

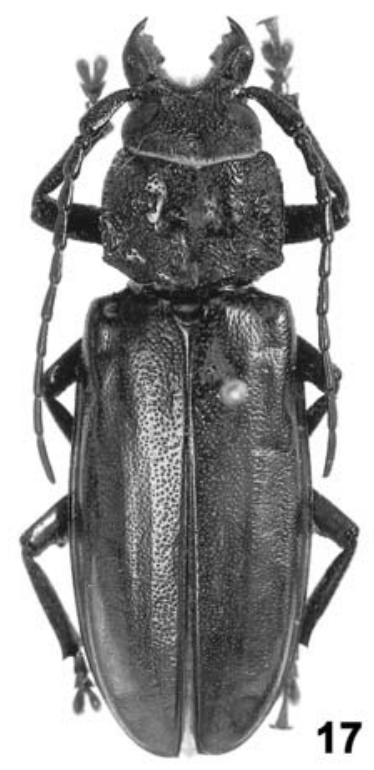

17

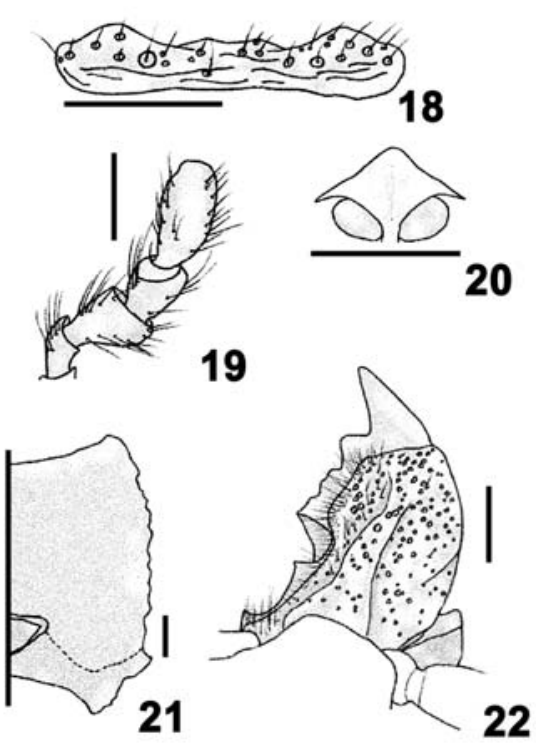


16.X.2000, fêmea, 27-29.X.2000, Wappes \& Morris col. (USNM); macho, 22-31.X.2002, Wappes \& Morris col. (MZSP); fêmea, 18.XI.2002, Wappes \& Morris col. (USNM). BRASIL. Mato Grosso: Poconé, fêmea, XI.1988, B. Raffer col. (MNRJ); Rosário Oeste, fêmea, X.1960, sem nome do coletor (MNRJ); fêmea, X.1960, sem nome do coletor (MZSP); fêmea, XI.1960, macho, X.1961, sem nome do coletor (MNRJ); macho, X.1967, A. Maller col. (MNRJ); fêmea, X.1968, sem nome do coletor (MNRJ); macho, X.1968, fêmea, X.1969, A. Maller col. (MNRJ); macho, X.1972, A. Maller col. (MZSP); 1 macho e 1 fêmea, X.1972, fêmea, XI-XII.1974, sem nome do coletor (MNRJ).

Discussão. Assemelha-se a P. crassidens (Bates, 1869) pela forma da mandíbula, mas difere principalmente pelo prosterno fortemente intumescido. É semelhante também a P. dohrnii, da qual diferencia-se notavelmente pela forma das mandíbulas.

\section{Physopleurus crassidens (Bates, 1869)}

(Figs. 23 - 29)

Mallodonhoplus crassidens Bates, 1869: 45; Gemminger \& Harold, 1872: 2768 (cat.).

Stenodontes (Mallodonhoplus) crassidens; Lameere, 1902: 85.

Physopleurus crassidens; Lameere, 1912: 126; 1913: 15 (cat.); 1919: 35; Blackwelder, 1946: 553 (cat.); Monné \& Giesbert, 1994: 6 (cat.); Monné, 1995: 15 (cat.); Fragoso \& Monné, 1995a: 220.

Acréscimos à descrição do macho (Fig. 23). Antenômero III mais longo do que o IV. Segundo artículo dos palpos maxilares subigual ao terceiro (Gérard Tavakilian, comunicação pessoal). Espinho dos ângulos laterais do protórax salientes; ângulos anteriores arredondados; ângulos posteriores obtusos. Pronoto cerradamente pontuado nas laterais e região basal (exceto uma faixa sublisa no centro); depressão puntiforme na região centrobasal.

Descrição. Fêmea (Fig. 24). Tamanho grande (49-60 mm). Tegumento castanho-escuro; élitros opacos.

Fronte com pontos grandes, profundos, anastomosados. Área posterior dos olhos rugosa. Clípeo deprimido; pontuação rasa e pilosidade esparsa. Sutura coronal bem marcada. Suturas frontais distintas em direção aos ápices, nítidas ou não, próximo à sutura coronal. Área do anteclípeo com pilosidade e escultura iguais às da fronte; regiões laterais notavelmente projetadas para frente. Labro com pêlos longos; ápice obtuso. Ápice das genas pouco projetado e fracamente aguçado. Mento (Fig. 25) cerca de 7 vezes mais largo do que longo. Submento fortemente elevado (em uma das fêmeas, o submento é obliquamente elevado). Gula deprimida. Distância entre os ápices das paraglossas (Fig. 26) aproximadamente 5,5 vezes menor do que a largura da cabeça (Fig. 16). Artículos II e III dos palpos maxilares (Fig. 28) iguais em comprimento. Mandíbulas (Fig. 27) com a carena dorsal baixa ou moderadamente elevada na base; margem interna com pêlos longos, dispersos, um dente triangular, pequeno, localizado junto ao apical, outro triangular, grande, aproximadamente no meio e, um dente pequeno, entre o anterior e a área molar (nos dois espécimes examinados, esse último dente é inconspícuo na mandíbula direita). Antenas atingem o terço basal dos élitros; escapo não ultrapassa a borda posterior do olho, fracamente alargado em direção ao pedicelo; antenômero III mais longo que o antenômero IV e com cerca de $3 / 4$ do comprimento do escapo.
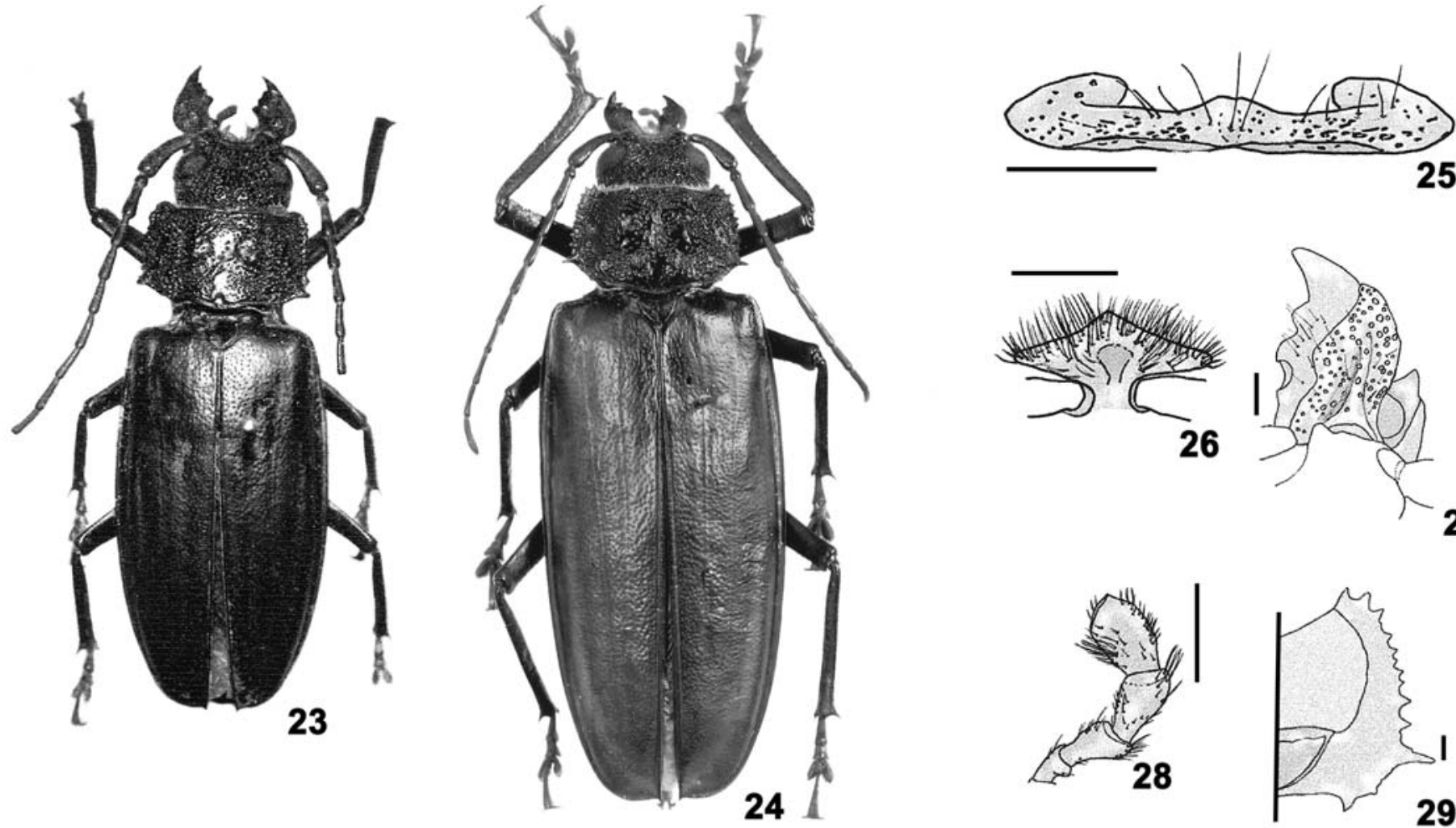

Figs. 23-29. Physopleurus crassidens. 23, holótipo macho; 24, fêmea, comprimento, 60,2 mm; 25, mento; 26, lígula, face externa; 27, mandíbula direita; 28, palpo maxilar; 29, protórax, ventral. Barra $=1 \mathrm{~mm}$. 
Protórax com comprimento, no centro, cerca de 0,55 vezes a maior largura (medida no ápice dos espinhos das bordas laterais); bordas laterais crenadas. Borda anterior do pronoto côncava e fracamente sinuosa; cantos anteriores pouco projetados; ângulos das bordas laterais com espinho longo; ângulos posteriores obtusos ou nulos; disco pronotal elevado, com calosidades fortemente pontuadas, exceto uma faixa central unida a uma área triangular na base, que são sublisas; laterais com pontos grandes anastomosados. Prosterno fracamente intumescido, com pontos rasos em quase toda extensão ou com pontos grandes e bem marcados nas laterais e pequenos no centro; pilosidade curta e esparsa. Ápice do processo prosternal largamente arredondado. Suturas prosternais (Fig. 29) fracamente arqueadas. Proepisternos (Fig. 29) estreitados em direção à cabeça. Metasterno glabro, liso e brilhante no centro, microesculturado e pubescente nas laterais e região anterior. Metepisternos com escultura igual à das laterais do metasterno. Élitros com pontuação cerrada e rasa; ápices elitrais com espinho. Asas translúcidas. Fêmures espinhosos na borda ínfero-distal. Protíbias fortemente espinhosas; meso- e metatíbias com alguns espinhos pequenos e dispersos; esporão apical externo das protíbias, longo, voltado para dentro.

Dimensões, em mm (fêmea). Comprimento total, 49,8-60,2; protórax: largura anterior, 9,8-10,2; largura entre os espinhos dos ângulos das margens laterais, 14,2-15,8; comprimento do pronoto (centro), 8,1-9,0; largura umeral, 15,0-17,6; comprimento elitral, 35,0-42,3.

Tipo, localidade-tipo. Holótipo macho, BRASIL, Amazonas, Ega [atual Tefé], depositado no MNHN.

Discussão. Bates (1869) descreveu a espécie em Malodonhoplus e modificou a definição das mandíbulas desse gênero para incluí-la. LAMEERE (1912) transferiu-a para o então subgênero Stenodontes (Physopleurus) baseando-se principalmente na forma das mandíbulas. O exame de diapositivo (feito por J. S. Moure) e foto (por G. Tavakilian) do holótipo e das duas fêmeas examinadas, demonstram que LAMEERE (l. c.) estava correto.

Material examinado. BRASIL. Amazonas: Manaus (Aeroporto), fêmea, 26.IX.1984 (MNRJ); Mato Grosso: Jacaré (Parque Nacional do Xingu), fêmea, XI.1961, Alvarenga e Werner col. (MNRJ).

Physopleurus longiscapus Lameere, 1912 (Figs. $30-45$ )

Physopleurus longiscapus Lameere, 1912: 127; 1913: 15 (cat.); Blackwelder, 1946: 553 (cat.); Monné \& Giesbert, 1994: 6 (cat.); Monné, 1995: 15 (cat.).

Redescrição. Macho (Fig. 30). Tamanho grande. Tegumento castanho-escuro.

Fronte com pontos grandes, profundos, em parte anastomosados. Área posterior dos olhos opaca e com asperezas dispersas. Clípeo deprimido; escultura formada por pontos rasos, anastomosados e pequenas asperezas dispersas, exceto na região de confluência das suturas frontais e coronal, que é lisa e brilhante, e regiões laterais, nitidamente ásperas; pilosidade curta e esparsa. Suturas coronal e frontais marcadas. Área do anteclípeo com pêlos eretos, abundantes nas laterais e mais esparsos no centro. Labro com pêlos longos e esparsos; ápice em ângulo obtuso. Ápice das genas obtuso e pouco projetado. Mento (Fig. 33) aproximadamente 8,5 vezes mais largo do que longo. Submento elevado e largo. Gula deprimida. Distância entre os ápices das paraglossas (Figs. 32, 35, 36) aproximadamente 6 vezes menor do que a largura da cabeça (Fig. 16). Segundo artículo dos palpos maxilares (Fig. 34) mais longo do que o terceiro. Mandíbulas (Fig. 39) com a carena dorsal moderadamente elevada na base; margem interna com pêlos longos e esparsos, um dente grande largamente truncado, localizado junto ao apical, outro triangular ou subtriangular, aproximadamente no meio, e um dente pequeno próximo à área molar. Antenas atingem o meio dos élitros (às vezes pouco antes do meio); escapo ultrapassa a borda posterior do olho, fortemente alargado em direção ao pedicelo; antenômero III subigual ou pouco mais longo que o antenômero IV.

Protórax com comprimento, no centro, cerca de 0,5 vezes a maior largura; bordas laterais nitidamente crenadas. Borda anterior do pronoto côncava, com a metade interna de cada lado reta e a metade externa suavemente sinuosa; cantos anteriores projetados; ângulos das bordas laterais com espinho curto; ângulos posteriores nulos; disco pronotal com calosidades brilhantes e pontos pequenos esparsos; laterais com pontos grandes anastomosados. Prosterno pouco intumescido, com pontos pequenos e profundos e pêlos curtos, esparsos. Ápice do processo prosternal liso e truncado. Suturas prosternais (Fig. 37) arqueadas. Proepisternos (Fig. 37) rugosos. Metasterno liso e brilhante no centro, micropontuado nas laterais e região anterior. Metepisternos com microasperezas e pilosidade. Élitros cerradamente pontuados; ápices elitrais com espinho. Asas (Fig. 118) translúcidas. Lobo médio (Figs. 41 - 43) com comprimento igual à cerca de 1,5 o do tégmen (Figs. 44, 45); comprimento das apófises basais igual a 0,75 vezes o comprimento total do lobo médio. Fêmures espinhosos na borda ínfero-distal. Todas as tíbias espinhosas; esporão apical externo das protíbias moderadamente curto, voltado para baixo.

Fêmea (Fig. 31). Mandíbulas (Fig. 40) mais curtas; dente da margem interna, junto ao dente apical, aguçado. Antenas atingem apenas o terço basal dos élitros; escapo mais curto (apenas ultrapassa a borda posterior do olho). Prosterno quase liso. Proepisternos (Fig. 38) pouco mais largos.

Dimensões, em mm (macho / fêmea). Comprimento total, 41,5-72,3 / 54,8-77,8; protórax: largura anterior, 9,0-17,5 / 10,015,0; largura entre os espinhos dos ângulos das margens laterais, 11,2-20,3 / 14,3-20,3; comprimento do pronoto (centro), 6,1-10,3/ 7,5-10,9; largura umeral, 11,6-22,0 / 14,8-22,5; comprimento elitral, 11,6-48,0/37,3-53,5.

Tipos, localidade-tipo. Dois síntipos, macho e fêmea, PERU, Loreto, Iquitos, depositados no ISNB (não examinados).

Discussão. Esta espécie é muito semelhante a $P$. rugosus 
(Gahan, 1894), mas difere: escapo mais curto; prosterno apenas suavemente intumescido; proepisternos mais largos; pontuação do pronoto e dos élitros mais fraca.

Material examinado. COLÔMBIA, Putumayo: Puerto Colón (luz), fêmea, III.1970, H. Salazar col. (MZSP). EQUADOR, Napo: Tena, macho, 5.XI.1980, sem nome do coletor (MNRJ). PERU, Loreto: Pucallpa, fêmea, 1.IX.1968, fêmea, 21.IX.1968, Schunke col. (MNRJ). BRASIL, Amazonas: Benjamin Constant, macho, IV.1957, G. Lima col. (MNRJ); 1 macho e 1 fêmea, XI.1960, macho, XI.1962, fêmea, IV.1963,
1 macho e 2 fêmeas, IV.1964, macho, XI.1964, sem nome do coletor (MZSP); fêmea, XI.1979, A. Peixoto col. (MNRJ); (Sítio Amazonas), 2 fêmeas, IV.1964, sem nome do coletor (MZSP); (Rio Javari), macho, sem data, sem nome do coletor (MZSP); Manaus, macho, 5.XI.1957, David Silva col. (MNRJ); Maués, fêmea, 7.XII.1936, sem nome do coletor (MNRJ); (Rio Javari), macho, 1959, J. Hidaz col. (MNRJ); São Paulo de Olivença, fêmea, J. F. Zikán col.(MZSP); Pará: Cachimbo, macho, XI.1954, J. A. Araújo col. (MNRJ); fêmea, X.1955, Pe. Pereira col. (MZSP); 2 machos, X.1956, Travassos Oliveira \& Adão col.(MNRJ); fêmea, X.1959, M. Alvarenga col. (MNRJ); fêmea, sem data e nome do coletor (MZSP); Itaituba (Santaremsinho), macho, IV.1964, sem nome
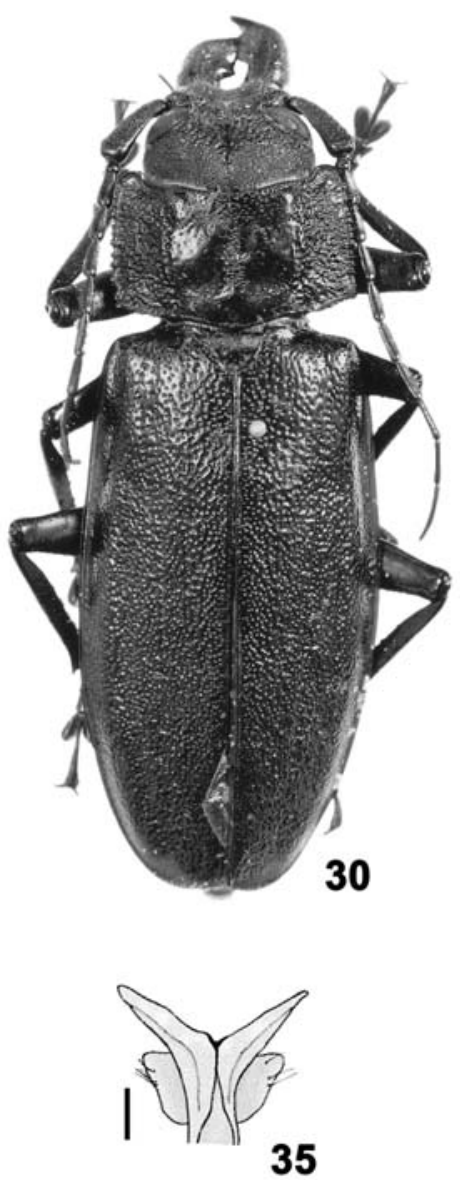
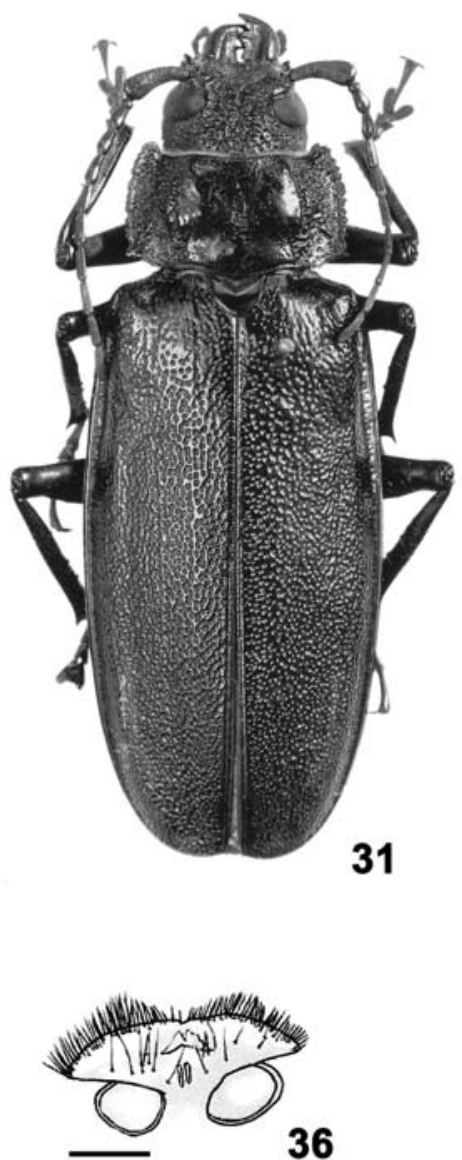

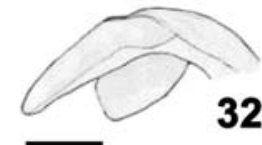

32

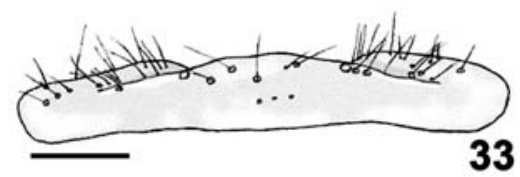

34
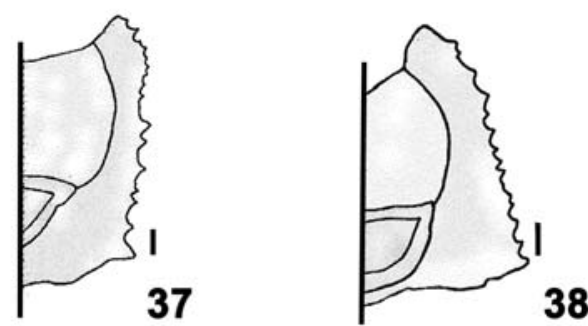
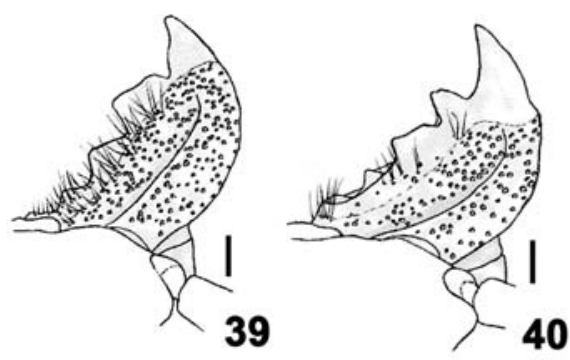
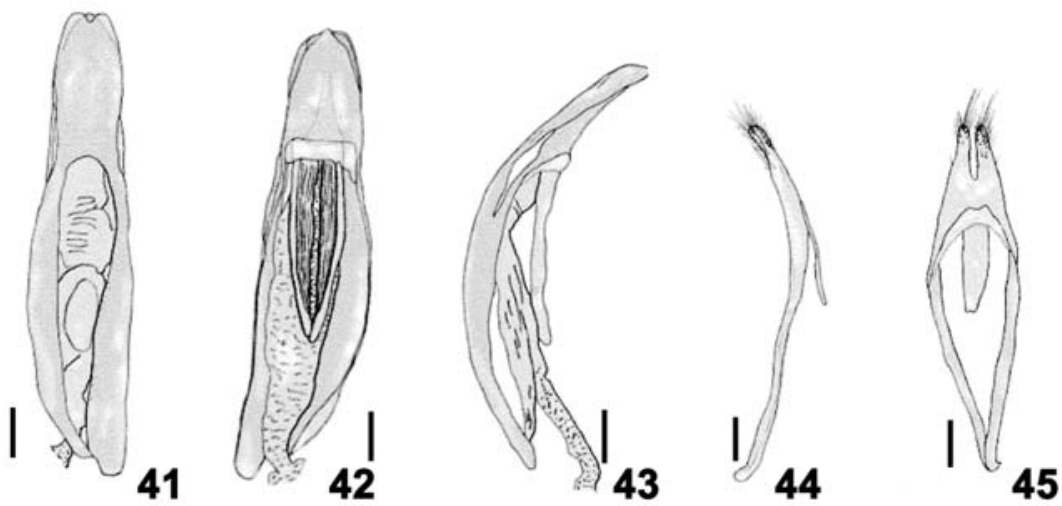

Figs. 30-45. Physopleurus longiscapus. 30, macho, comprimento, $72,3 \mathrm{~mm} ; \mathbf{3 1}$, fêmea, comprimento, 77,8 mm; 32, 35-36, lígula: 32, lateral; 35, face interna; 36, face externa; 34, maxila; 37-38, protórax, ventral: 37, macho; 38, fêmea; 39-40, mandíbula direita: 39, macho; 40, fêmea; 41-43, lobo médio: 41, dorsal; 42, ventral; 43, lateral; 44-45, tégmen: 44, lateral; $\mathbf{4 5}$, dorsal. Barra $=1 \mathrm{~mm}$. 
do coletor (MZSP); Óbidos, macho, II.1931, B. Pohl col. (MZSP); fêmea, XII.1956, A. Maller col.(MNRJ); macho, I.1959, fêmea, II.1960, sem nome do coletor (MNRJ); Serra dos Carajás, macho, XI.1991, L. S. Otero col. (MNRJ); Serra Norte, macho, 2.XI.1983, M. Zanuto col. (MZSP); Mato Grosso: Comodoro, macho, X.1968, P. Magno \& J. Becker col., 1 macho e 3 fêmeas, XI.1987, O. Roppa \& P. Magno col. (MNRJ); Porto Velho (Rio Tapirapé), macho, XII.1962, C. Pinheiro col. (MZSP); Rosário Oeste, macho, X.1968, sem nome do coletor, (MNRJ); Sinop $\left(12^{\circ} 31^{\prime} \mathrm{S}, 55^{\circ} 37^{\prime} \mathrm{W}-\mathrm{BR} 163\right.$, km 500 a $\left.600-350 \mathrm{~m}\right)$, fêmea, Roppa e Alvarenga col. (MNRJ); Vera (12 $\left.46^{\prime} \mathrm{S}, 55^{\circ} 36^{\prime} \mathrm{W}\right), 1$ macho e 5 fêmeas, X.1973, M. Alvarenga \& Roppa col. (MNRJ).

Physopleurus rugosus (Gahan, 1894)

(Figs. 46-56)

Basitoxus rugosus Gahan, 1894: 224.

Physopleurus rugosus; Lameere, 1913: 15 (cat.); 1919: 35; Blackwelder, 1946: 553 (cat.); Monné \& Giesbert, 1994: 6 (cat.); Monné, 1995: 15 (cat.); Tavakilian in Hequet, 1996: sem paginação, pl. III, fig. 4.

Redescrição. Macho (Fig. 46). Tamanho grande. Tegumento castanho-escuro.
Fronte com pontos grandes, profundos, anastomosados. Área posterior do olho áspera. Clípeo deprimido; pontuação esparsa, mais concentrada em direção às genas; pilosidade longa e esparsa. Sutura coronal bem marcada. Suturas frontais distintas em direção aos ápices. Área do anteclípeo com pontos rasos confluentes, asperezas dispersas e pêlos iguais aos do clípeo, porém mais concentrados. Labro subliso, com pêlos longos na região centro-apical; ápice obtuso. Ápice das genas aguçado e projetado. Mento (Fig. 48) cerca de 6 vezes mais largo do que longo. Submento suavemente elevado. Gula deprimida, rugosa em direção às fossas tentoriais, cerradamente pontuado em direção à margem anterior. Distância entre os ápices das paraglossas (Figs. 50 - 52) aproximadamente 5 vezes menor do que a largura da cabeça (Fig. 16). Segundo artículo dos palpos maxilares (Fig. 49) mais longo do que o terceiro. Mandíbulas (Fig. 55) com a carena dorsal elevada da base até o quarto apical; margem interna com pêlos curtos, moderadamente concentrados no terço basal, longos e esparsos até a base do dente apical, e 3 dentes: um grande,
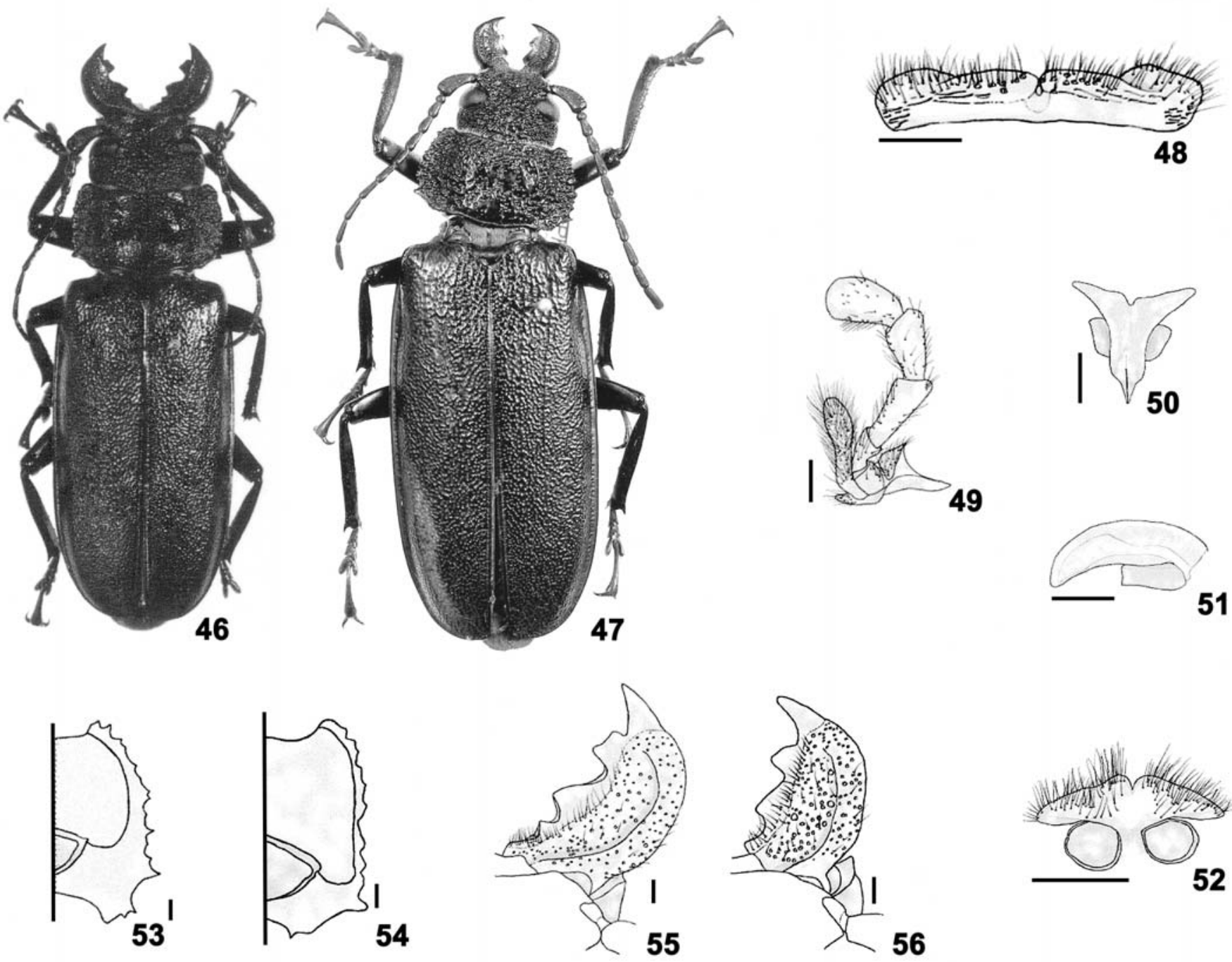

Figs. 46-56. Physopleurus rugosus. 46, macho, comprimento, 73,7 mm; 47, fêmea, comprimento, $61,0 \mathrm{~mm}$; 48, mento; 49, maxila; 50-52, lígula: 50, face interna; 51, lateral; 52, face externa; 53-54, protórax, ventral: 53, fêmea; 54, macho; $\mathbf{5 5} \mathbf{- 5 6}$, mandíbula direita: 55, macho; 56, fêmea. Barra $=1 \mathrm{~mm}$. 
truncado, localizado junto ao dente apical; outro grande, triangular, aproximadamente no meio; um pequeno, triangular, próximo à área molar. Antenas atingem o terço basal dos élitros; escapo ultrapassa um pouco a borda posterior do olho, fortemente alargado em direção ao pedicelo; antenômero III subigual ou pouco mais curto que o antenômero IV.

Protórax com comprimento, no centro, cerca de 0,55 vezes a maior largura; bordas laterais nitidamente crenadas. Borda anterior do pronoto côncava e sinuosa; cantos anteriores projetados; ângulos das bordas laterais com espinho curto; ângulos posteriores fortemente obtusos; disco pronotal com calosidades brilhantes e esparsamente pontuadas; escultura entre as calosidades formada por pontos pequenos e cerrados; laterais com pontos grandes anastomosados. Prosterno intumescido, com pontos pequenos e profundos, e raros pêlos curtos. Ápice do processo prosternal projetado, liso e arredondado. Suturas prosternais (Fig. 54) arqueadas. Proepisternos (Fig. 54) fortemente estreitados. Metasterno liso e brilhante no centro, micropontuado nas laterais e região anterior (nessas regiões há ainda pontos esparsos, maiores e profundos). Metepisternos com microasperezas e pilosidade. Élitros cerradamente pontuados; ápices elitrais apenas salientes (sem espinho nítido). Asas (Fig. 119) castanhas. Fêmures espinhosos na borda ínfero-distal. Todas as tíbias espinhosas (principalmente as anteriores); esporão apical externo das protíbias, moderadamente curto, voltado para baixo.

Fêmea (Fig. 47). Cabeça menor do que no macho. Mandíbulas (Fig. 56) semelhantes às do macho. Escapo mais curto (não ultrapassa a borda posterior do olho). Disco do pronoto com pontuação mais grossa. Proepisternos (Fig. 53) pouco mais largos.

Dimensões, em mm (macho / fêmea). Comprimento total, 73,7 / 61,0-76,0; protórax: largura anterior, 15,0 / 11,0-14,0; largura entre os espinhos dos ângulos das margens laterais, 18,9 / 15,8-19,0; comprimento do pronoto (centro), 10,0/ 8,0-10,4; largura umeral, 20,0 / 17,0-22,0; comprimento elitral, 42,8 /38,051,2 .

Tipos, localidade-tipo. Síntipos macho e fêmea, GUIANA FRANCESA (Caiena), depositados no BMNH. Examinamos diapositivo de um síntipo macho, feito por J. S. Moure.

Biologia. TAVAKILIAN (1996) disse sobre P. rugosus: "Rare espèce qui se capture au piégeage lumineux notamment en février entre quatre heures du matin et l'aube".

Discussão. Espécie rara nas coleções. Gérard Tavakilian, que coletou durante anos na Guiana Francesa, dispõe de apenas mais dois exemplares machos na coleção do MNHN (comunicação pessoal), além do relacionado em material examinado.

Material examinado. GUIANA FRANCESA, Caiena: Estrada de

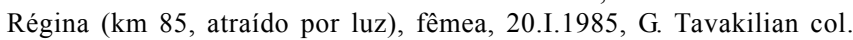
(MNHN); Estrada de Kaw (km 38, atraído por luz), 11.II.1986, P. Cremieux col. (MNHN). BRASIL, Amapá: Serra do Navio, fêmea, VI.1960, Bicelli col.(MZSP); Amazonas: Itacoatiara, fêmea, I.1965, sem nome do coletor (MZSP); Pará: Óbidos, fêmea, sem data, sem nome do coletor (MZSP).

\section{Physopleurus tritomicros Lameere, 1912}

(Figs. 57 - 65)

Physopleurus tritomicros Lameere, 1912: 126; 1913: 15 (cat.); 1919: 35; Blackwelder, 1946: 553 (cat.); Monné \& Giesbert, 1994: 6 (cat.); Fragoso \& Monné, 1995a: 220; Monné, 1995: 15 (cat.); Tavakilian in Hequet, 1996: sem paginação, pl. II, fig. 5.

Redescrição. Macho (Fig. 57). Tamanho grande. Tegumento castanho-escuro.

Fronte com pontuação grossa, profunda e pêlos curtos esparsos. Área posterior dos olhos opaca e gradualmente passa de pontuada a rugosa. Clípeo deprimido, microesculturado, com pequenas asperezas dispersas, onde se implanta um pêlo curto. Suturas coronal e frontais indistintas. Área do anteclípeo com pontos rasos, anastomosados e pêlos curtos dispersos. Labro pontuado, com pêlos longos na metade basal e liso com raros pêlos na metade apical; ápice aguçado. Ápice das genas fortemente projetado e aguçado. Mento (Fig. 59) aproximadamente 5 vezes mais largo do que longo. Submento gradualmente elevado e com pontuação esparsa e fina. Gula deprimida. Lígula suavemente bilobada. Distância entre os ápices das paraglossas (Fig. 61) cerca de 5 vezes menor do que a largura da cabeça (Fig. 16). Segundo artículo dos palpos maxilares (Fig. 60) mais longo do que o terceiro. Mandíbulas (Fig. 65) alongadas, com carena dorsal moderadamente elevada nos $2 / 3$ basais; margem interna com pêlos e três dentes: um truncado ou subtriangular, junto ao dente apical; um triangular, pouco antes do meio; outro triangular no terço basal. Antenas atingem o meio dos élitros; escapo ultrapassa a borda posterior do olho, cerradamente pontuado; antenômero III cerca de 0,3 vezes o comprimento do escapo e mais curto do que o antenômero IV.

Protórax com comprimento, no centro, cerca de 0,6 vezes a maior largura; bordas laterais crenadas. Borda anterior do pronoto côncava; cantos anteriores suavemente obtusos, pouco projetados; ângulos das bordas laterais e posteriores com espinho; disco pronotal com calosidades brilhantes e pontos pequenos, esparsos; laterais com pontos grandes anastomosados e pêlos dispersos. Prosterno intumescido, com pontos grossos e profundos, a maioria não-confluente, e pêlos curtos. Ápice do processo prosternal saliente, arredondado, quase liso e com raros pêlos curtos. Suturas prosternais (Fig. 62) apenas indicadas. Limites entre o prosterno e os proepimeros distintos apenas pela diferença na escultura. Proepisternos (Fig. 62) fortemente estreitados. Metasterno subliso e brilhante no centro; laterais e região anterior com pontos finos, cerrados e pilosidade mais abundante do que no disco. Metepisternos com pontos pequenos e rasos; pilosidade igual à das laterais do metasterno. Élitros fina e abundantemente pontuados e com carenas baixas, mas nítidas; ápice sutural com espinho. Fêmures fina e esparsamente pontuados. Tíbias cerradamente pontuadas e com pêlos curtos; protíbias com espinhos na face externa; meso- e metatíbias inermes; esporão apical externo das protíbias curto, voltado para baixo. 


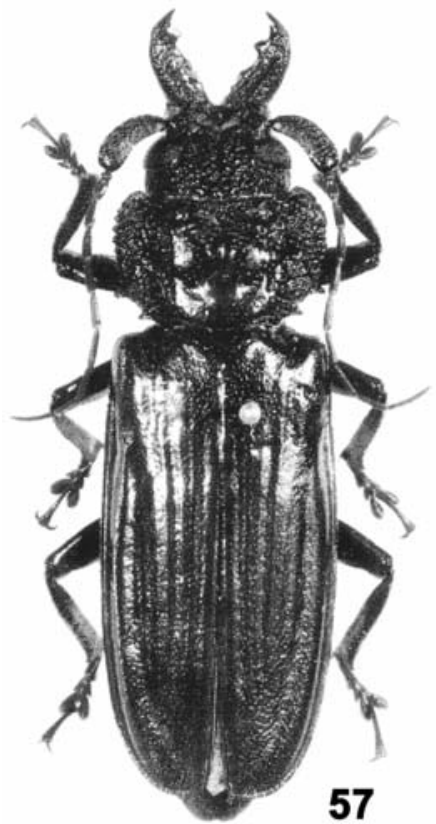

57

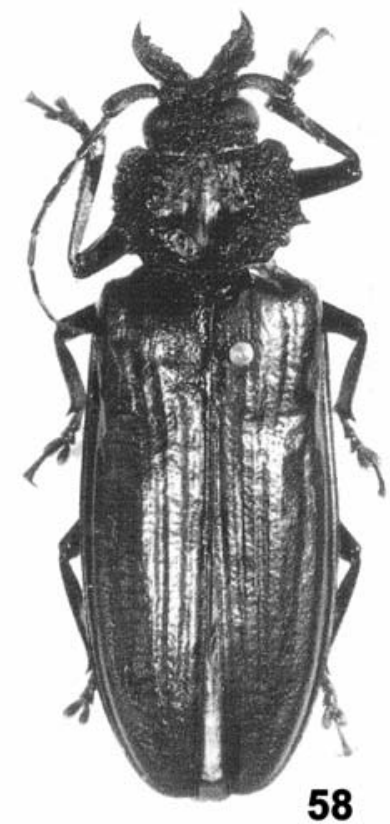

58

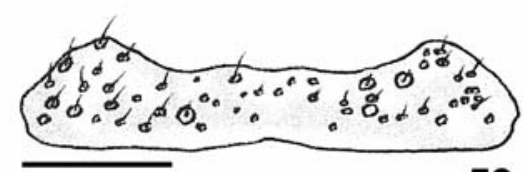

59
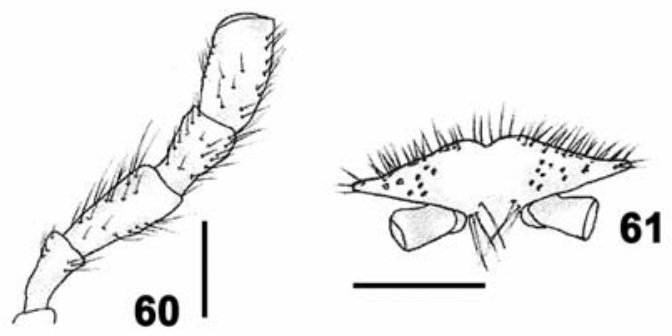
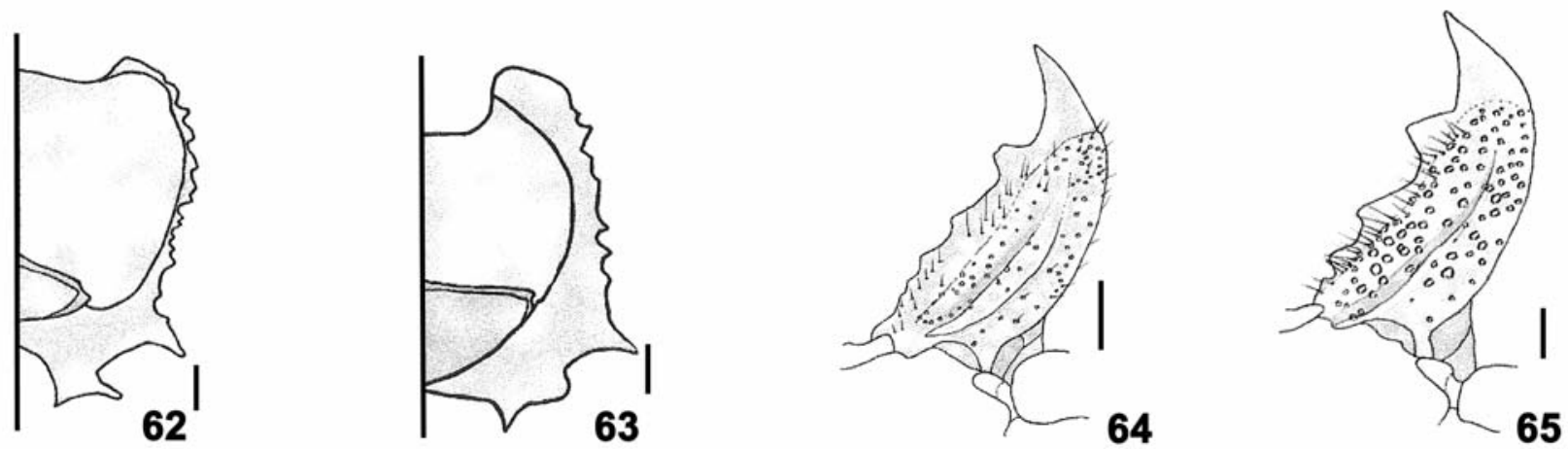

Figs. 57-65. Physopleurus tritomicros. 57, macho, comprimento, $52,9 \mathrm{~mm}$; 58, fêmea, comprimento, $54,5 \mathrm{~mm}$; 59, mento; 60, palpo maxilar; 61, lígula, face externa; 62-63, protórax, ventral: 62, macho; 63, fêmea; 64-65, mandíbula direita: 64, fêmea; 65 , macho. Barra = 1 mm.

Fêmea (Fig. 58). Mandíbulas (Fig. 64) proporcionalmente mais curtas. Antenas atingem apenas o quarto basal dos élitros; escapo não atinge a borda posterior do olho. Proepisternos (Fig. 63) mais largos. Suturas prosternais nítidas. Élitros proporcionalmente mais longos.

Dimensões, em mm (macho / fêmea). Comprimento total, $52,9 / 54,5$; protórax: largura anterior, 10,0 / 9,0; largura entre os espinhos dos ângulos das margens laterais, 13,3 / 14,2; comprimento do pronoto (centro), 8,1 / 8,0; largura umeral 13,5 / 14,8; comprimento elitral, 30,1/36,3.

Tipos, localidade-tipo. Três síntipos, um macho e duas fêmeas, da GUIANA FRANCESA (Caiena e Saint Laurent du Maroni), ex-coleção Gounelle, depositados no MNHN. Examinamos diapositivos de dois síntipos, um macho e uma fêmea, feitos por J. S. Moure.

Discussão. $P$. tritomicros é a espécie que apresenta as mandíbulas proporcionalmente mais longas e os élitros mais nitidamente carenados.

Material examinado. GUIANA FRANCESA, Caiena: Estrada de Kaw ( $\mathrm{km} \mathrm{33,} \mathrm{atraído} \mathrm{por} \mathrm{luz),} \mathrm{macho,} \mathrm{30.I.1984,} \mathrm{G.} \mathrm{Tavakilian} \mathrm{col.} \mathrm{(MNHN);}$ (km 40, atraído por luz), fêmea, 29.VI.1984, G. Tavakilian col. (MNHN).

\section{Physopleurus seripierriae sp. nov.}

(Figs. 66 - 71)

Etimologia. A espécie é dedicada à Dione Seripierri, Bibliotecária do MZSP pelas inúmeras gentilezas.

Fêmea (Fig. 66). Tamanho grande. Tegumento castanhoescuro; élitros avelãs, com a sutura, bordas e úmeros, mais acastanhados.

Fronte com pontos grandes, profundos, anastomosados. Área posterior dos olhos opaca e com asperezas pequenas e dispersas. Clípeo deprimido; escultura formada por pequenas 
asperezas dispersas, exceto a região de confluência das suturas frontais e coronal que é lisa e brilhante e regiões laterais nitidamente ásperas; pilosidade curta e esparsa, mais concentrada junto aos tubérculos anteníferos. Sutura coronal bem marcada. Suturas frontais indistintas. Área do anteclípeo com pilosidade e escultura iguais às do clípeo. Labro com pêlos longos e esparsos; ápice fortemente aguçado e inclinado em direção à região ventral. Ápice das genas projetado e aguçado. Mento (Fig. 67) cerca de 6-7 vezes mais largo do que longo, com pilosidade longa e abundante. Submento elevado e largo. Gula deprimida. Distância entre os ápices das paraglossas (Fig. 69) aproximadamente 6 vezes menor do que a largura da cabeça (Fig. 16). Segundo artículo dos palpos maxilares (Fig. 68) pouco mais longo do que o terceiro. Mandíbulas (Fig. 71) com a carena dorsal baixa; margem interna com alguns pêlos longos, dispersos, e três dentes triangulares: um grande, localizado junto ao apical; um pequeno, aproximadamente no meio (às vezes ausente) e outro pequeno, próximo à área molar (às vezes, o dente central está fundido a este dente e forma uma placa larga). Antenas atingem o terço basal dos élitros; escapo não ultrapassa a borda posterior do olho, fracamente alargado em direção ao pedicelo; antenômeros III e IV iguais em comprimento ou o III um pouco mais curto.

Protórax com comprimento, no centro, cerca de 0,5 vezes a maior largura (medida no ápice dos espinhos das bordas laterais); bordas laterais crenadas. Borda anterior do pronoto côncava e nitidamente sinuosa; cantos anteriores projetados; ângulos das bordas laterais com espinho longo; ângulos posteriores distintos, obtusos ou fracamente agudos; disco pronotal elevado, com calosidades fortemente pontuadas, exceto uma faixa central unida a uma área triangular na base, que são sublisas; laterais com pontos grandes anastomosados (em um dos parátipos, essa pontuação invade quase completamente o disco). Prosterno pouco intumescido, com pontos rasos, asperezas pequenas e dispersas, e alguns pêlos curtos. Ápice do processo prosternal em nível mais baixo do que o restante da estrutura, liso, arredondado ou subaguçado. Suturas prosternais (Fig. 70) fracamente arqueadas.
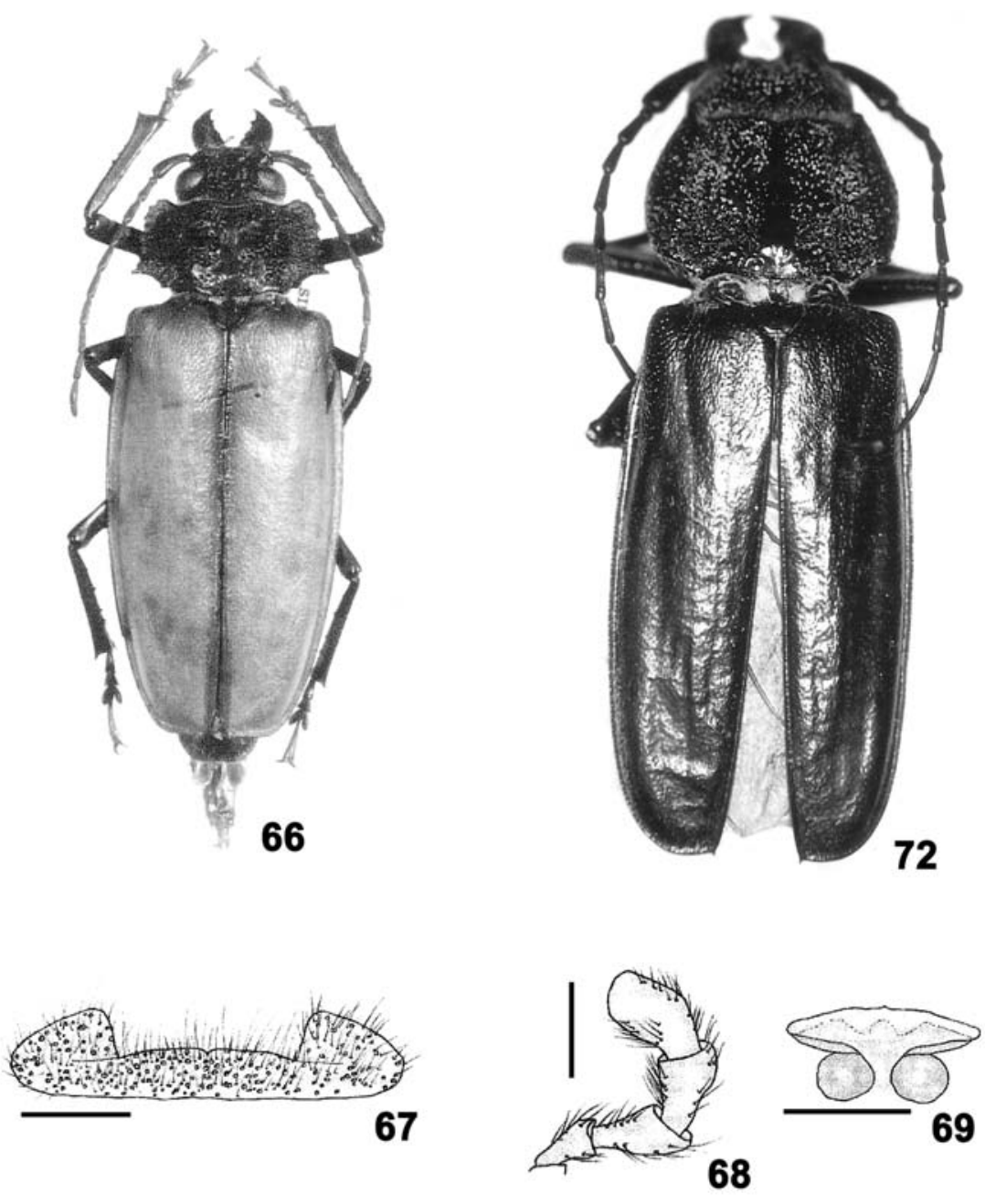

68
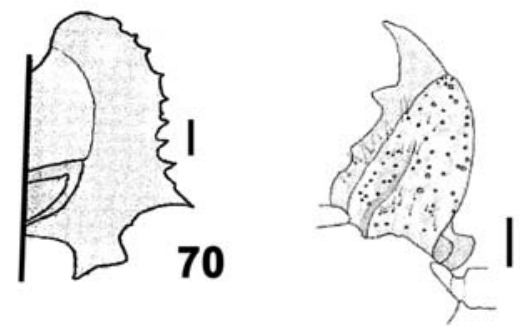

Figs. 66-73. 66-71, Physopleurus seripierriae sp. nov., holótipo fêmea, comprimento, 50,2 mm; 67, mento; 68, palpo maxilar; 69, lígula, face externa; 70, protórax, ventral; 71, mandíbula direita. Barra =1 mm. $72-73$, Physopleurus dohrnii. 72, macho (BMNH); 73, fêmea (NHRS). 
Proepisternos (Fig. 70) largos. Metasterno glabro, liso e brilhante no centro, microesculturado e pubescente nas laterais e região anterior. Metepisternos com escultura igual às das laterais do metasterno. Élitros com pontuação cerrada e rasa; ápices elitrais com espinho nítido. Asas (Fig. 121) castanhas. Fêmures espinhosos na borda ínfero-distal. Todas as tíbias fortemente espinhosas; esporão apical externo das protíbias, longo, voltado para dentro.

Dimensões, em mm (fềmea). Comprimento total, 50,2-62,0; protórax: largura anterior, 10,5-12,0; largura entre os espinhos dos ângulos das margens laterais, 15,2-18,1; comprimento do pronoto (centro), 7,4-8,9; largura umeral, 15,8-18,8; comprimento elitral, 35,0-43,7.

Material-tipo. Holótipo fêmea. BRASIL. Mato Grosso: Sinop $\left(12^{\circ} 31^{\prime} \mathrm{S}, 55^{\circ} 37^{\prime} \mathrm{W}\right.$ BR $163, \mathrm{Km} 500$ a $\left.600-350 \mathrm{~m}\right)$, X.1975, Roppa \& Alvarenga col.(MNRJ). Parátipos: BRASIL. Mato Grosso: fêmea, sem

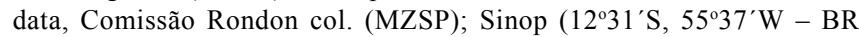
163, Km 500 a $600-350$ m), fêmea, X.1974, Alvarenga e Roppa col. (MNRJ).

Discussão. É a espécie cujas suturas prosternais apresentam menor curvatura em direção ao pronoto (provavelmente as suturas do macho são mais curvadas). Assemelha-se a Yalissus tuberculatus (Olivier, 1795) pela coloração geral, espinhos das tíbias e escultura do pronoto; difere pelo tamanho da cabeça e pelos caracteres do gênero.

\section{Physopleurus dohrnii Lacordaire, 1869} (Figs. 72 - 73)

Physopleurus Dohrnii Lacordaire, 1869: 121.

Physopleurus Dohrni (sic); Gemminger \& Harold, 1872: 2769 (cat.); Lameere, 1912: 126; 1913: 15 (cat.); 1919: 35

Stenodontes (Physopleurus) Dohrni (sic); Lameere, 1902: 88; 1903: 214.

Physopleurus dohrni (sic); Blackwelder, 1946: 553 (cat.); Monné \& Giesbert, 1994: 6 (cat.); Fragoso \& Monné, 1995a: 220.

Physopleurus dohrnii; Monné, 1995: 15 (cat.).

Fragoso \& MonNÉ (1995b) escreveram: "Rosales (1966:105, pl. 5 fig. 2) mentioned, based on a unique male $28 \mathrm{~mm}$ long.: "...el [elytral angle] apical interno bien marcado, con una espina corta y aguda", a character omitted by Lacordaire (1869) and Lameere (1902)". Embora tanto Lameere (1902) como LACORDAIRE (1869) tenham omitido a presença de espinho no canto sutural dos élitros, a figura apresentada por LAMEERE (1919) mostra nitidamente tal caráter (espinhos curtos). É provável que a espécie descrita por Rosales (1966) realmente não seja $P$. dohrnii, mas só o estudo dos exemplares poderá, ou não, confirmar. Rosales ( $l . c$. ) disse: "Desafortunadamente, los ejemplares estudiados son de una talla que está muy por debajo del tamaño menor citado para la especie, por lo que no se pueden hacer observaciones y comparaciones generalizadas, especialmente en lo referente al tamaño de las mandíbulas, pues casi siempre en los ejemplares machos de menor talla aquellas son muy similares a las de las hembras." No entanto, nas espécies em que estudamos machos de diversos tamanhos, mesmo nos exemplares de grande porte, a diferença entre as mandíbulas dos dois sexos é muito pequena. Em P. longiscapus, espécie da qual examinamos machos de tamanhos muito diferentes, as mandíbulas não sofrem modificação significativa. Rosales $(l . c$. ) citou, ainda, outros caracteres no tórax que estão em desacordo tanto com a descrição de LACORDAIRE (1869), quanto com a redescrição de LAMEERE (l. c.): prosterno não-visível em vista dorsal; protórax mais transversal; pontuação escassa no prosterno. RosALES (op. cit.) também não mencionou os pontos mais grossos e esparsos, entre os pontos finos, no metasterno e a pilosidade desse esclerito.

Não obtivemos nenhum exemplar da espécie para estudo, mas acreditamos que a redescrição da espécie, apresentada por LAMEERE (1902) está correta. Examinamos diapositivos de um macho (Fig. 72) e de uma fêmea (Fig. 73) depositados, respectivamente, no BMNH e NHRS, feitos pelo padre J. S. Moure, e foto da mesma fêmea (ventral e dorsal) feita pelo Dr. Bert Viklund. Muito provavelmente, esta é uma das fêmeas que foram estudadas por Lameere e, embora não apresente espinho nítido nos ápices elitrais, concorda muito bem com as descrições e com o macho fotografado.

Tipo, localidade-tipo. Holótipo macho, VENEZUELA (Coleção Dohrn). Atualmente o holótipo deveria estar depositado no ZMPA, mas o Dr. Tomasz Huflejt (comunicação pessoal) observou que, apesar de haver um exemplar proveniente da Venezuela e existir um rótulo de gaveta indicando que o tipo está presente naquela coleção, o exemplar não possui rótulo de tipo e o comprimento é de aproximadamente 41 mm, o que contrasta com a indicação de LACORDAire (1869): "50 mm".

\section{Physopleurus villardi (Lameere, 1902)}

(Figs. 74 - 90)

Stenodontes (Physopleurus) villardi Lameere, 1902: 87.

Physopleurus villardi; Lameere, 1913: 14 (cat.); 1919: 35; Blackwelder, 1946: 553 (cat.); Monné \& Giesbert, 1994: 6 (cat.); Monné, 1995: 15 (cat.); Fragoso \& Monné, 1995a: 220.

Aplagiognathus guatemalensis Casey, 1912: 227; Lameere, 1919: 32 [= Stenodontes (Mallodon) dasystomus masticator Thomson, 1867]; Blackwelder, 1946: 552 (cat., in syn.); Linsley, 1957: 4; Chemsak et al., 1992: 15 (cat., in syn.); Monné \& Giesbert, 1994: 7 (cat., in syn.); Maes et al., 1994: 5 (cat., in syn.) Syn. nov.

Redescrição. Macho (Fig. 74). Tamanho médio a grande. Tegumento castanho-escuro.

Fronte com pontos grandes, profundos, anastomosados (aumentam de tamanho em direção à fronte), cada um com um pêlo curto. Área posterior dos olhos com pontos igualmente anastomosados, menores do que os do vértice, gradualmente substituídos por asperezas e estrias em direção à gula; pilosidade curta e esparsa. Clípeo deprimido; escultura formada por pontos anastomosados, rasos próximo à sutura coronal e moderadamente profundos próximo à área do clípeo e laterais; região de confluência das suturas frontais e coronal quase lisa, brilhante; pilosidade conspícua. Suturas coronal e frontais nãonítidas em toda extensão. Área do anteclípeo com pêlos eretos e abundantes. Labro pontuado e com pêlos longos moderadamente cerrados; ápice largamente obtuso. Ápice das 

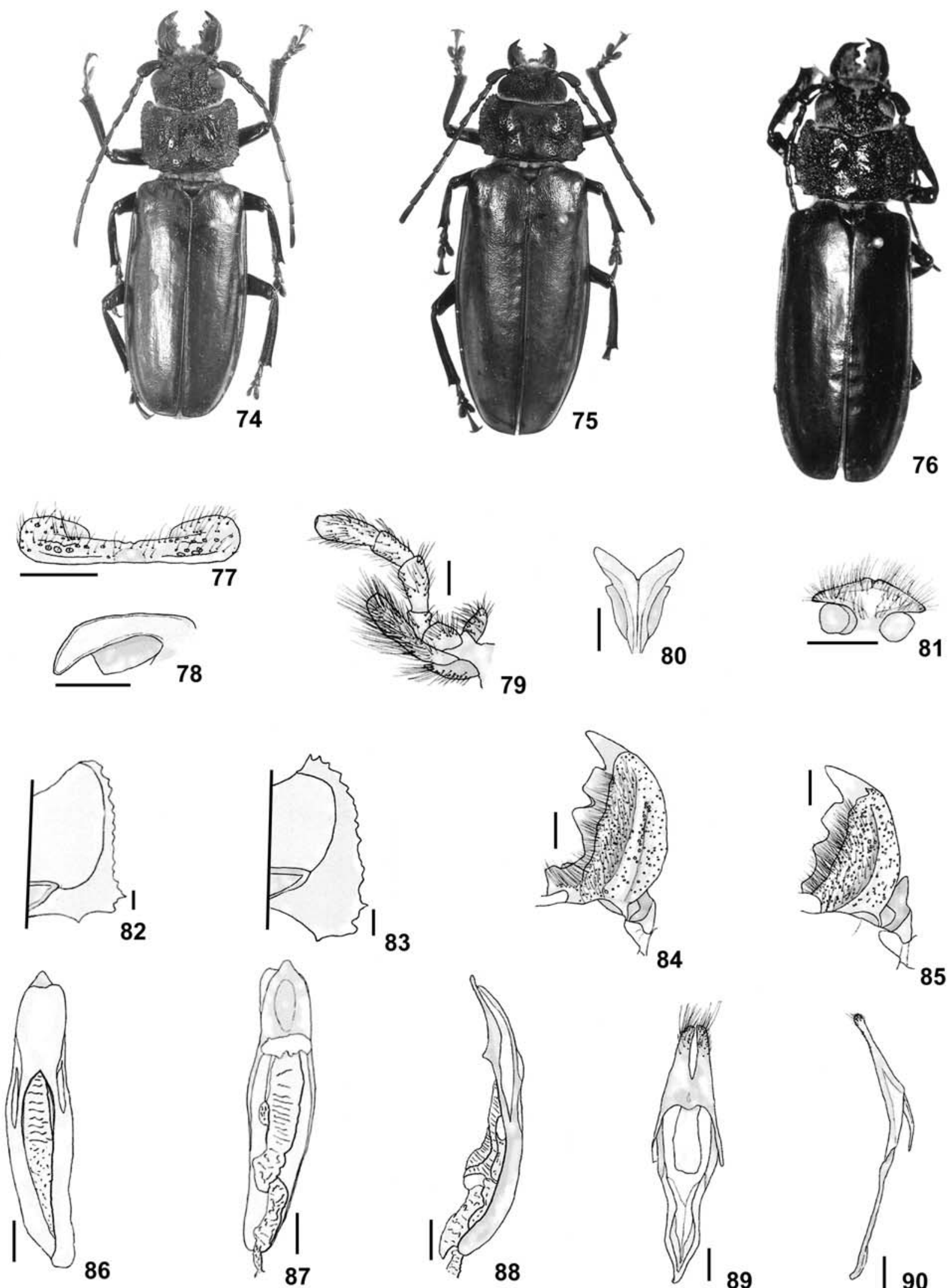

Figs. 74-90. 74-75, Physopleurus villardi. 74, macho, comprimento, 52,5 mm; 75, fêmea, comprimento, 50,7 mm. 76, Aplagiognathus guatemalensis, holótipo macho. 77-90, Physopleurus villardi. 77, mento; 78, 80-81, lígula: 78, lateral; 80, face interna; 81, face externa; 79, maxila; 82-83, protórax, ventral: 82, macho; 83, fêmea; 84-85, mandíbula direita: 84, macho; 85, fêmea; 86-88, lobo médio: 86, dorsal; 87, ventral, 88, lateral; 8990, tégmen: 89, dorsal; 90, lateral. Barra $=1 \mathrm{~mm}$. 
genas projetado e agudo. Mento (Fig. 77) cerca de 7-9 vezes mais largo do que longo. Submento elevado e largo, com pêlos longos e abundantes. Gula deprimida, com pêlos longos e esparsos. Distância entre os ápices das paraglossas (Figs. 78, $80,81)$ cerca de 5-6 vezes menor do que a largura da cabeça (Fig. 16). Segundo artículo dos palpos maxilares (Fig. 79) mais longo do que o terceiro. Mandíbulas (Fig. 84) com carena dorsal elevada que termina junto à base do dente apical; margem interna com pêlos longos, abundantes e quatro dentes: um grande, largamente truncado, localizado junto ao apical; um triangular, aproximadamente no meio; dois dentes juntamente protraídos (um pequeno e outro grande), próximos à área molar. Antenas atingem o meio dos élitros (às vezes um pouco mais curtas); escapo não ultrapassa a borda posterior do olho, suavemente alargado em direção ao pedicelo; comprimento do antenômero III igual ou pouco maior que o do antenômero IV.

Protórax com comprimento, no centro, aproximadamente 0,6 vezes a maior largura; bordas laterais crenadas. Borda anterior do pronoto côncava; cantos anteriores projetados ou apenas salientes; ângulos das bordas laterais com espinho curto; ângulos posteriores com espinho curto, agudos ou suavemente obtusos; disco pronotal com calosidades brilhantes e pontos pequenos esparsos; laterais com pontos grandes anastomosados. Prosterno intumescido, glabro, com pontos grandes, profundos e anastomosados. Ápice do processo prosternal liso e arredondado. Suturas prosternais (Fig. 82) arqueadas, distintas apenas próximo às cavidades coxais. Proepisternos (Fig. 82) rugosos, fortemente estreitados. Metasterno liso e brilhante no centro, micropontuado e pubescente nas laterais e região anterior. Metepisternos com pontos pequenos e cerrados; pilosidade conspícua. Élitros finamente pontuados; ápices elitrais com espinho curto. Asas (Fig. 122) translúcidas. Lobo médio (Figs. 86 - 88) com comprimento igual ao do tégmen (Figs. 89,90 ); comprimento das apófises basais igual a 0,7 vezes o comprimento total do lobo médio. Fêmures inermes. Tíbias fortemente pontuadas, sem espinhos, com pêlos curtos e esparsos nas regiões dorsal e ventral, e longos na face interna; esporão apical externo das protíbias, moderadamente curto, voltado para baixo.

Fêmea (Fig. 75). Mandíbulas (Fig. 85) mais curtas. Antenas atingem apenas o terço basal dos élitros; escapo mais esguio. Protórax mais transversal (comprimento, no centro, aproximadamente 0,5 vezes a maior largura). Ângulos anteriores do pronoto mais aguçados. Pontuação do prosterno mais fina e menos profunda. Proepisternos (Fig. 83) mais largos.

Dimensões, em mm (macho / fêmea). Comprimento total, 45,6-52,5 / 50,7; protórax: largura anterior, 10,0-10,5 / 9,5; largura entre os espinhos dos ângulos das margens laterais, 12,2-12,8 / 13,7; comprimento do pronoto (centro), 7,0-7,6 / 7,2; largura umeral, 12,5-13,5 / 14,9; comprimento elitral, 28,9-30,2 / 33,3.

Tipos, localidade-tipo. P. villardi foi descrita com base em um macho e cinco fêmeas (síntipos) do EQUADOR, Guayas, Guayaquil, pertencentes às coleções do BMNH, ZMHB, ZMUH e coleção M. Villard (incorporada à coleção do MNHN). O holótipo de Aplagiognathus guatemalensis é um macho, proveniente da GUATEMALA (Esquintla), depositado no USNM.
Biologia. Sobre P. villardi, CAmpos (1939) escreveu: "El referido coleóptero de amplia dispersión en el Ecuador Occidental, constituye para las poblaciones litorales una verdadera "peste domiciliaria". En Guayaquil puedo afirmar que "no existe casa alguna (de madera o material mixto) libre de gravoso insecto" cuyas larvas ocasionan perjuicios a las construcciones, perforando las vigas y soleras por todas las partes. El adulto aparece sin interrupción durante todos los meses del año y con mayor frecuencia y número por las noches, acudiendo a la luz. Yo lo he capturado en mi domicilio centenares de veces y en ocasiones casi a diário. El Stenodontes Villardi varía considerablemente de tamaño, viéndose ejemplares que oscilam entre 60 y 35 milímetros (incluídas las mandíbulas). La hembra efectúa un desove de 60 a 180 gérmenes, y la larva rompe la envoltura embrionária entre los 20 y 30 dias. Estimo que el cielo (sic) evolutivo completo de la espécie debe ocupar unos três años. Su amplitud genésica es digna de mención. Multitud de ocasiones he puesto a observación indivíduos tomados en libertad y siempre advertí la aproximación sexual. El insecto tiene hábitos crepusculares y vuela al caer la tarde con fuerte ruído. En la época invernal y en noches calurosas es profundamente atraído por los focos eléctricos". No mesmo trabalho afirmou: "Aunque el Stenodontes Villardi suele hallarse en el monte, debajo de la corteza suelta de los troncos vetustos o derribados, su adaptación dentro de las construcciones urbanas es característica. He advertido este coleóptero en sus diversas fases morfológicas en árboles viejos de ceibo (Bombax pentandra) en comunidad con larvas de Euchroma gigantea" e ainda: "El adulto aparece sin interrupción durante todos los meses del año y con mayor frecuencia y número por las noches, acudiendo a la luz".

Discussão. LAMEERE (1902) ao descrever a espécie, disse: "Un mâle et cinq femelles de Guayaquil (Équateur); collections du British Museum, du Musée de Berlin, du Musée de Hambourg et de M. Villard". J. S. Moure fotografou o síntipo macho no BMNH e uma fêmea no MNHN (examinamos os diapositivos). Damoiseau \& Cools (1987) referiram-se a um cótipo depositado no ISNB. WEIDNER $(1976,1979)$ não relacionou esta espécie na lista dos tipos depositados no ZMUH e WeNDT (1984) também não cita como depositada na coleção do ZMHB.

LAMEERE (1919) colocou Aplagiognathus guatemalensis Casey, 1912 (Fig. 76), com dúvida, na sinonímia de Stenodontes (Mallodon) dasystomus masticator (Thomson, 1867). BLACKWELDER (1946) manteve a espécie como válida. LiNSLEY (1957) escreveu: "Mallodon baroni Casey (from Guerrero, Mexico), placed questionably as a synonym of Stenodontes spinibarbis Linnaeus by Lameere, has the genae more or less tridentate as in S. dasystomus masticator (Thomson) and may be that subspecies. However, Aplagiognathus guatemalensis Casey (from Esquintla, Guatemala), assigned by Lameere as a possible synonym of $S$. dasystomus masticator Thomson, is quite distinct from what I have identified as masticator. Although apparently assignable to Stenodontes (Orthomallodon), it is unlike any species now known to me". O exame do diapositivo do holótipo de A. guatemalensis, 
demonstra que LinsLey (l. c.) estava correto em não aceitar a sinonímia proposta por LAmeERE (l. c.). No entanto, discordamos com relação à inclusão da espécie no então subgênero Stenodontes (Orthomallodon), que se caracteriza, segundo LINSLEY (1962): "Mandibles not strongly retracted at base, outer margin arcuate, inner margin densely pilose, without strong inner tooth before apex, those of male but little longer than head; antennae not surpassing middle of elytra in male, not attaining middle of elytra in female; metepisterna broad, inner margin straight or slightly convex". Apesar da descrição acima enfatizar a forma das mandíbulas, é justamente essa estrutura que permite distinguir facilmente $A$. guatemalensis das espécies outrora incluídas em $S$. (Orthomallodon): borda látero-externa subplana; carena dorsal forte da base até quase o ápice; área entre a carena e a margem interna subvertical; ápice acompanha a curvatura externa. Em Physopleurus: borda látero-externa arredondada; carena dorsal geralmente baixa; área entre a carena e a margem interna, sub-horizontal; ápice fortemente curvado. Atualmente, S. (Orthomallodon) é sinônimo de Mallodon Lepeletier \& Audinet-Serville, 1830 (ver Fragoso \& Monné, 1995a) e sua espécie-tipo, M. spinibarbis (Linnaeus, 1758), mostra claramente que LiNSLEY (1957) estava errado ao supor que A. guatemalensis pudesse ser incluída nesse gênero. Chemsak et al. (1992), MAes et al. (1994), Monné \& Giesbert (1994) e Monné (1995) mantiveram a sinonímia. Chemsak (1996) colocou Mallodon masticator na sinonímia de Mallodon dasystomus dasystomus.

Examinamos diapositivo do holótipo de A. guatemalensis feito por J. S. Moure no USNM e concluímos que o exemplar é um macho de $P$. villardi, embora apresente o protórax pouco mais transverso do que os outros exemplares estudados. Lingafelter (comunicação pessoal) não localizou o tipo no USNM, o que nos impossibilitou obter detalhes sobre a face ventral. Pelo exposto, $A$. guatemalensis é sinônimo de $P$. villardi.

Material examinado. EQUADOR. Guayas: Guayaquil, 3 machos e 2 fêmeas, sem data, Campos R. col., 1 macho e 1 fêmea, 1946, sem nome do coletor, 3 machos, sem data e nome do coletor (MNRJ).

\section{Physopleurus amazonicus (Fragoso \& Monné, 1995), comb. nov.} (Figs. 91 - 106)

Basitoxus (Parabasitoxus) amazonicus Fragoso \& Monné, 1995b: 723, figs. 4, 6, 9, 12, 20.

Acréscimos à descrição original. Macho (Fig. 91). Ápice do labro em ângulo obtuso. Ápice das genas aguçado e pouco projetado. Mento (Fig. 93) aproximadamente 8 vezes mais largo do que longo. Submento obliquamente elevado. Gula deprimida. Distância entre os ápices das paraglossas (Figs. 95 - 97) aproximadamente 5,5 vezes menor do que a largura da cabeça (Fig. 16). Segundo artículo dos palpos maxilares (Fig. 94) subigual ao terceiro em comprimento ou um pouco mais longo.

Protórax com comprimento, no centro, cerca de 0,6 - 0,7 vezes a maior largura. Borda anterior do pronoto uniformemente côncava ou com a metade interna de cada lado, reta e a metade externa suavemente sinuosa; cantos anteriores pouco projetados; ângulos das bordas laterais com espinho curto e largo, voltado para cima; ângulos posteriores nulos. Asas (Fig. 120) translúcidas. Lobo médio (Figs. 104 - 106) com comprimento aproximadamente igual ao do tégmen (Figs. 102 $103)$; comprimento das apófises basais igual a 0,7 vezes o comprimento total do lobo médio. Esporão apical externo das protíbias, curto, suavemente voltado para baixo.

Fêmea (Fig. 92). Dente da margem interna das mandíbulas (Fig. 100), junto ao dente apical, aguçado. Antenas atingem apenas o quarto basal dos élitros; escapo menos robusto. Prosterno quase liso. Proepimeros (Fig. 99) bem definidos.

Dimensões, em mm (macho / fêmea). Comprimento total, 45,9-58,3 / 45,2-55,8; protórax: largura anterior, 9,6-12,0 / 8,211,0 ; largura entre os espinhos dos ângulos das margens laterais, 11,7-14,9 / 10,7-14,6; comprimento do pronoto (centro), 7,2-9,7 / 6,5-8,5; largura umeral, 12,5-16,0 / 12,5-16,0; comprimento elitral, 28,8-36,0/31,1-37,5.

Tipos, localidade-tipo. Holótipo macho PERU, Huanuco, Tingo Maria, 22.XII.1968, J. Schunke col. e parátipo fêmea, do Brasil, Amapá, Serra do Navio, 28.X. 1957, K. Lenko col. depositados no MNRJ (examinados).

Material examinado. BRASIL. Amapá: Serra do Navio, fêmea, XI.1972, sem nome do coletor, fêmea, X.1995, P. Magno \& Alvarenga col. (MNRJ). Amazonas: Benjamin Constant, fêmea, XI.1960, sem nome do coletor (MZSP). Pará: Cachimbo, 2 fêmeas, IX.1954, Alvarenga col., macho, 25.IX.1956, Travassos, Oliveira \& Adão col., fêmea, X.1959, Alvarenga col. (MNRJ); fêmea, sem data e nome do coletor (MZSP); Itaituba (Santaremsinho), fêmea, IV.1964, sem nome do coletor (MZSP); Óbidos, macho, XI.1955, sem nome do coletor (MZSP); Santarém, fêmea, X.1977, sem nome do coletor (MNRJ). Mato Grosso: Coxim, fêmea, XI.1940, sem nome do coletor (MNRJ); Rio Verde, fêmea, XI.1962, sem nome do coletor, fêmea, X.1964, sem nome do coletor (MNRJ); Rosário Oeste, fêmea, XI.1960, sem nome do coletor, fêmea, XII.1960, sem nome do coletor, fêmea, X.1961, sem nome do coletor (MNRJ); Sinop $\left(12^{\circ} 31^{\prime} \mathrm{S}, 55^{\circ} 37^{\prime} \mathrm{W}\right.$ - BR 163 , km 500 a 600 - 350 m), fêmea, X.1974, sem nome do coletor, macho, XI.1975, Roppa \& Alvarenga col. (MNRJ).

\section{Physopleurus maillei (Audinet-Serville, 1832), comb. nov.} (Figs. 107 - 117)

Basitoxus Maillei Audinet-Serville, 1832: 175; Lacordaire, 1869: 119; Gemminger \& Harold, 1872: 2768 (cat.); Lameere, 1902: 86; 1912: 129; 1913: 11(cat.); 1919: 29

Stenodontes Maillei; Lameere, 1903: 214

Basitoxus maillei; Blackwelder, 1946: 552 (cat.); Monné \& Giesbert, 1994: 5 (cat.); Monné, 1995: 7 (cat.).

Basitoxus (Parabasitoxus) maillei; Fragoso \& Monné, 1995b: 721, figs. $3,5,8,11,13,15-18$.

Redescrição. Macho (Fig. 107). Tamanho grande. Tegumento castanho-escuro (cabeça, escapo e protórax mais escuros).

Fronte com pontuação anastomosada. Área posterior dos olhos opaca e com asperezas moderadamente concentradas. Clípeo deprimido; escultura formada por pontos rasos, exceto a região de confluência das suturas frontais e coronal, que é lisa e brilhante, e regiões laterais, que são nitidamente pontuadas; pilosidade curta e esparsa. Sutura coronal bem marcada. Suturas frontais apenas indicadas. Área do anteclípeo 

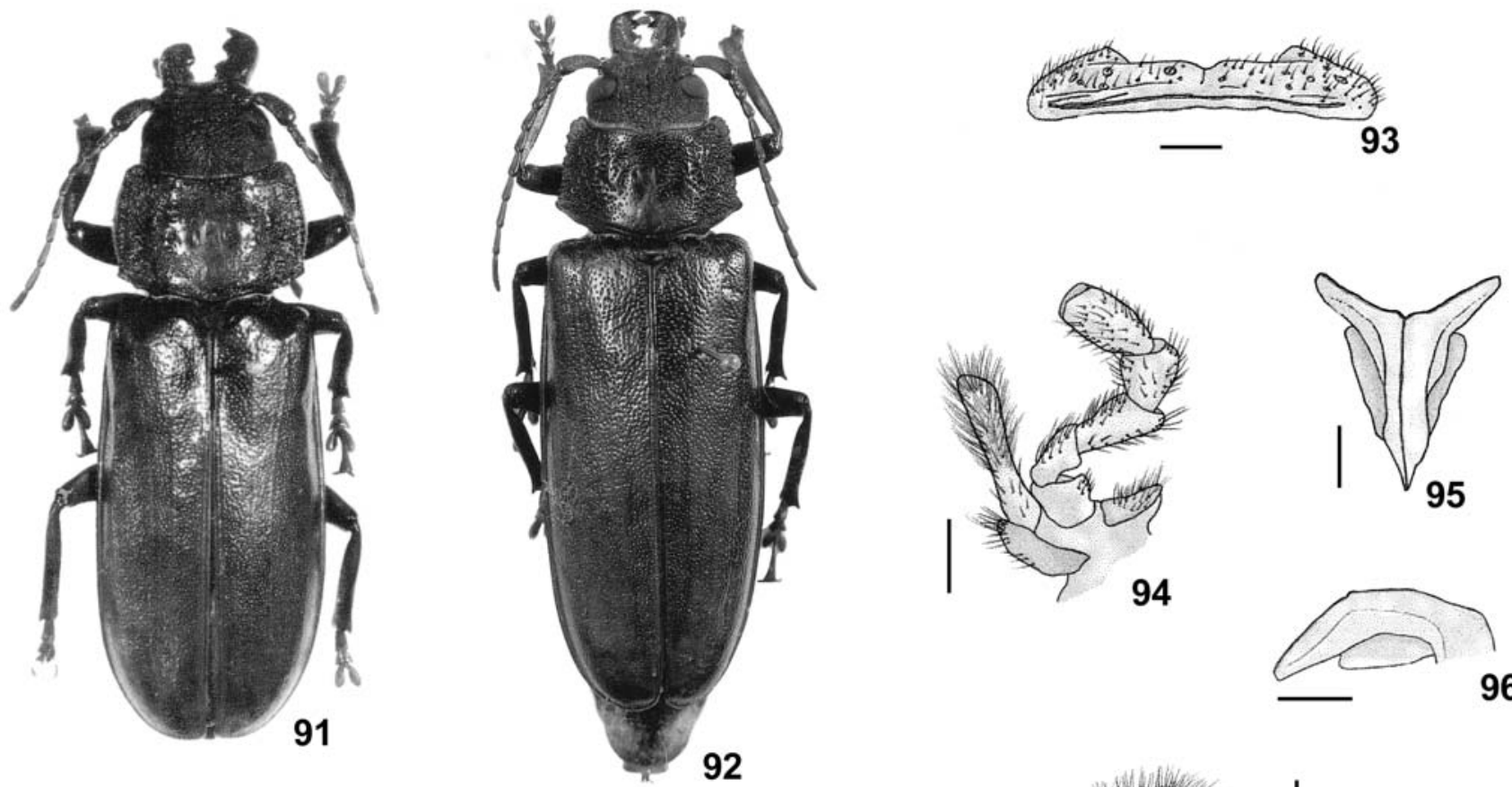

94
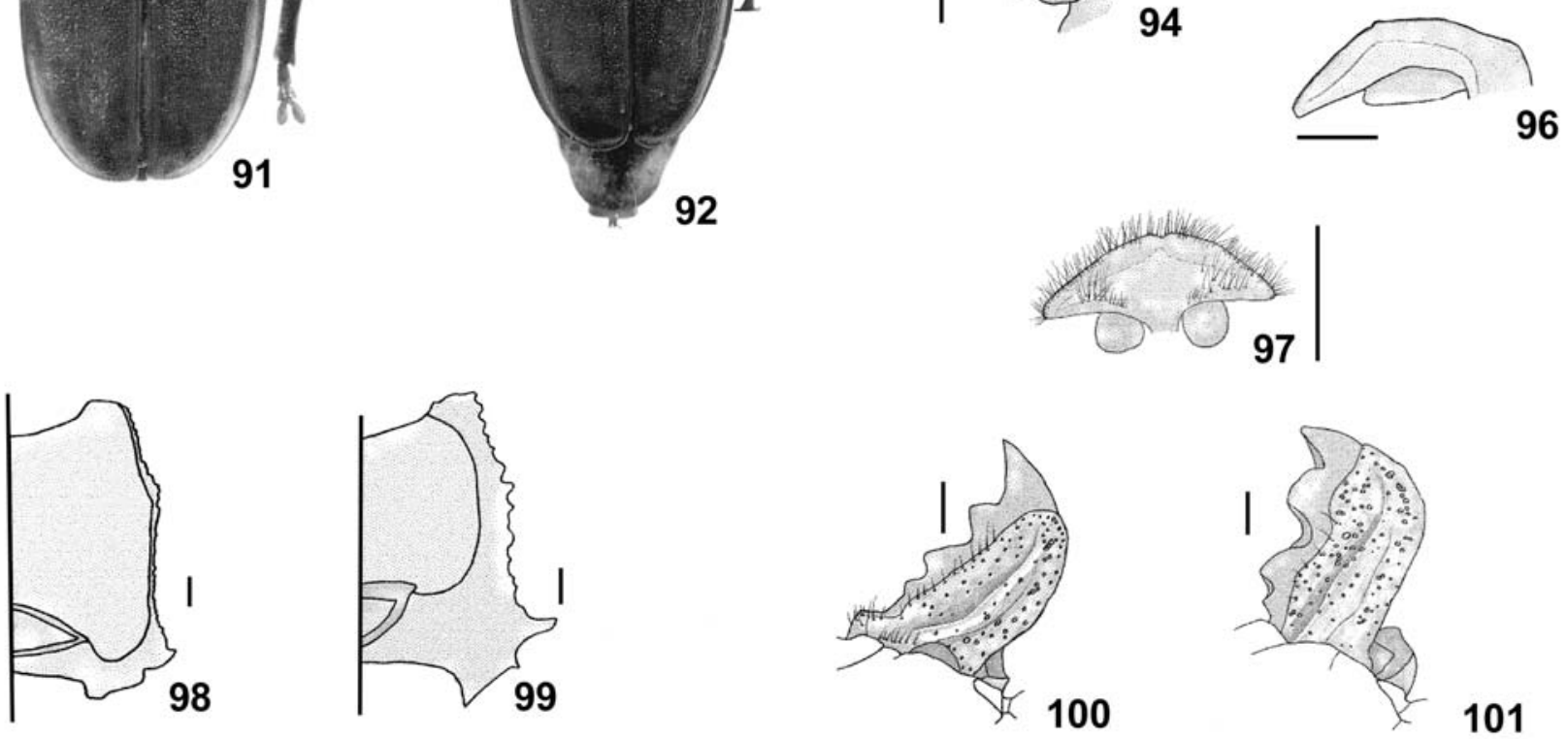

101
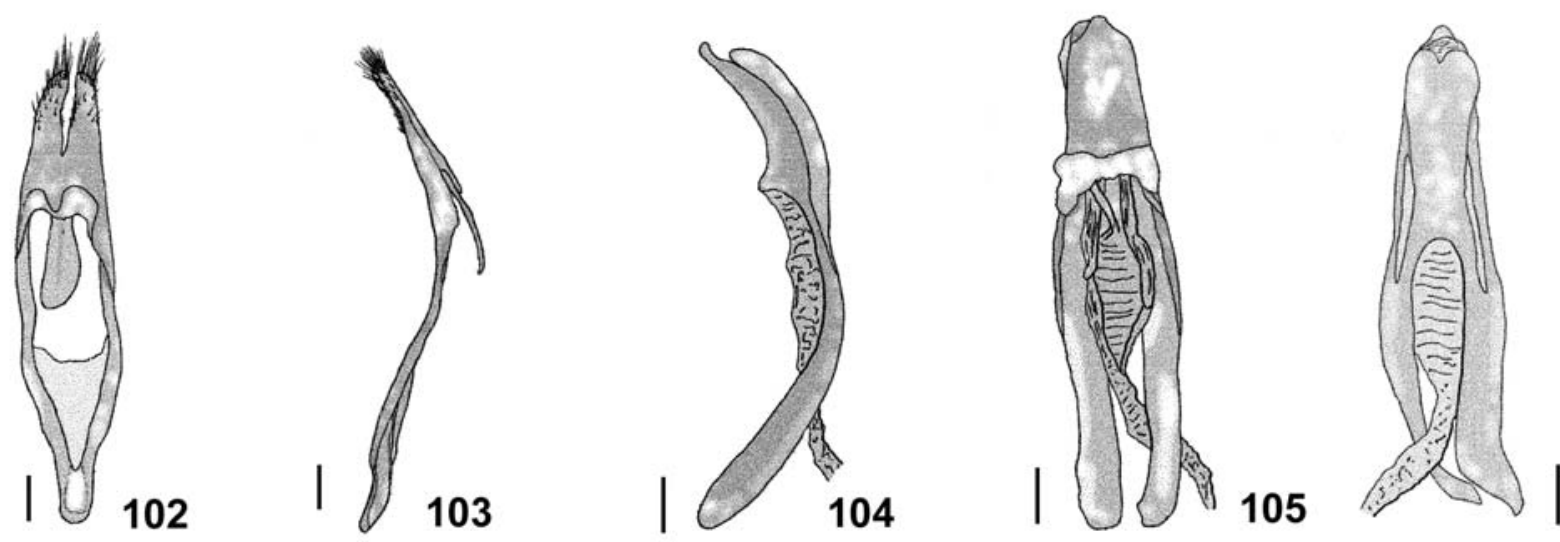

Figs. 91-106. Physopleurus amazonicus. 91, macho, comprimento, 58,3 mm; 92, fêmea, comprimento, 55,8 mm; 93, mento; 94, maxila; 95-97, lígula: 95, face interna; 96, lateral; 97, face externa; 98-99, protórax, ventral: 98, macho; 99, fêmea; 100-101, mandíbula direita: 100, fêmea; 101, macho; 102-103, tégmen: 102, dorsal; 103, lateral; 104-106, lobo médio: 104, lateral; 105, ventral; 106, dorsal. Barra $=1 \mathrm{~mm}$. 
com pêlos curtos e esparsos. Labro com pontos profundos na base; pilosidade mais longa e concentrada em direção ao ápice; terço apical notavelmente deprimido (às vezes suavemente); ápice arredondado. Ápice das genas projetado e fortemente aguçado. Mento (Fig. 109) aproximadamente 8,5 vezes mais largo do que longo. Submento suave e gradualmente elevado. Gula deprimida. Distância entre os ápices das paraglossas (Figs. 111 - 113) cerca de 4,5-5 vezes menor do que a largura da cabeça (Fig. 16). Segundo artículo dos palpos maxilares (Fig. 110) mais longo do que o terceiro. Mandíbulas (Fig. 117) com a carena dorsal baixa e larga (às vezes inconspícua); margem interna com pêlos dispersos e três dentes: um grande, largamente truncado, localizado junto ao apical (em alguns exemplares triangular); um triangular, aproximadamente no meio; outro triangular pequeno (às vezes esse dente é subigual ao anterior em tamanho), próximo à área molar. Antenas atingem apenas o terço basal dos élitros; escapo ultrapassa a borda posterior do olho, arqueado e alargado em direção ao pedicelo; comprimento dos antenômero III igual ou pouco menor que o do antenômero IV.
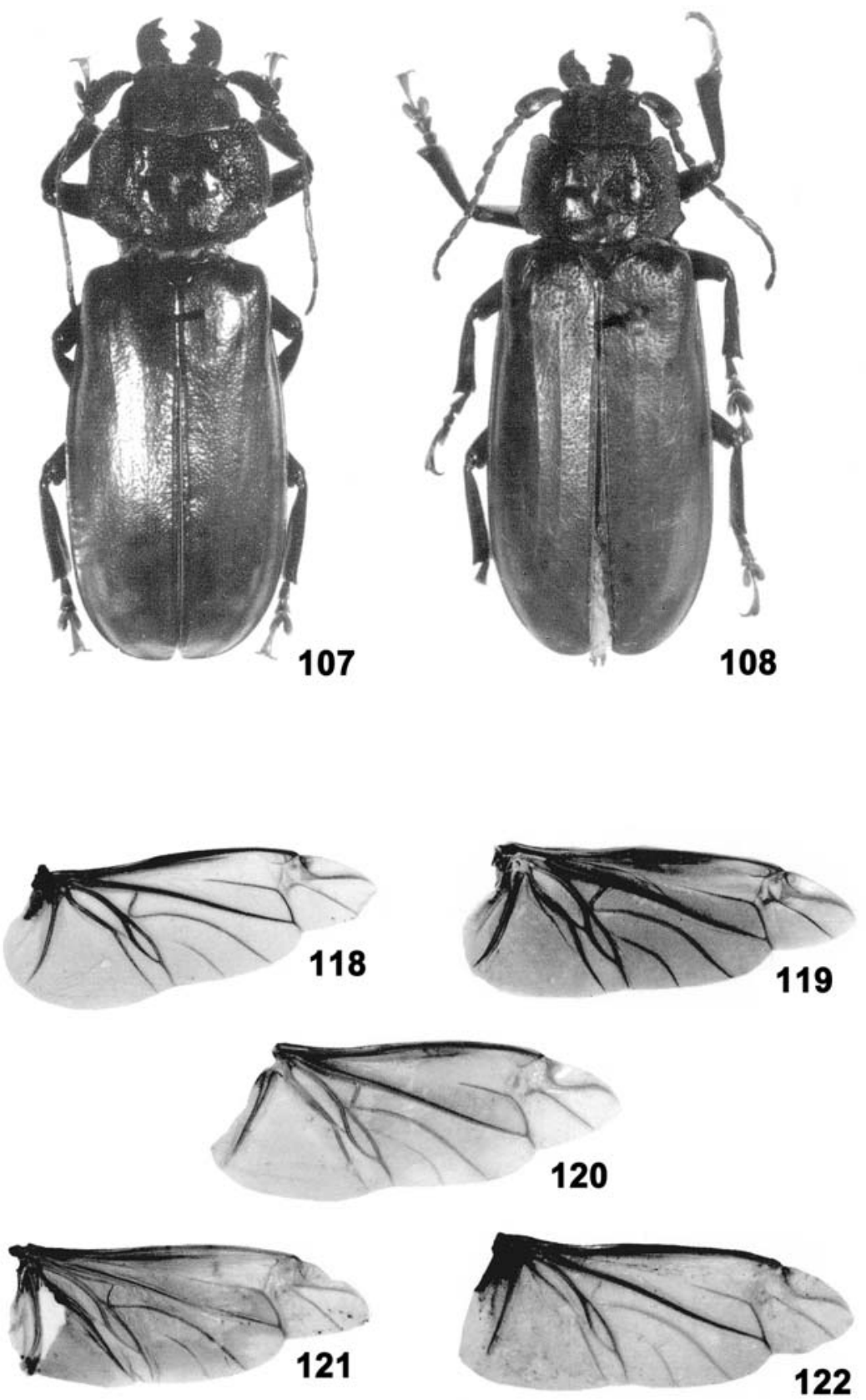
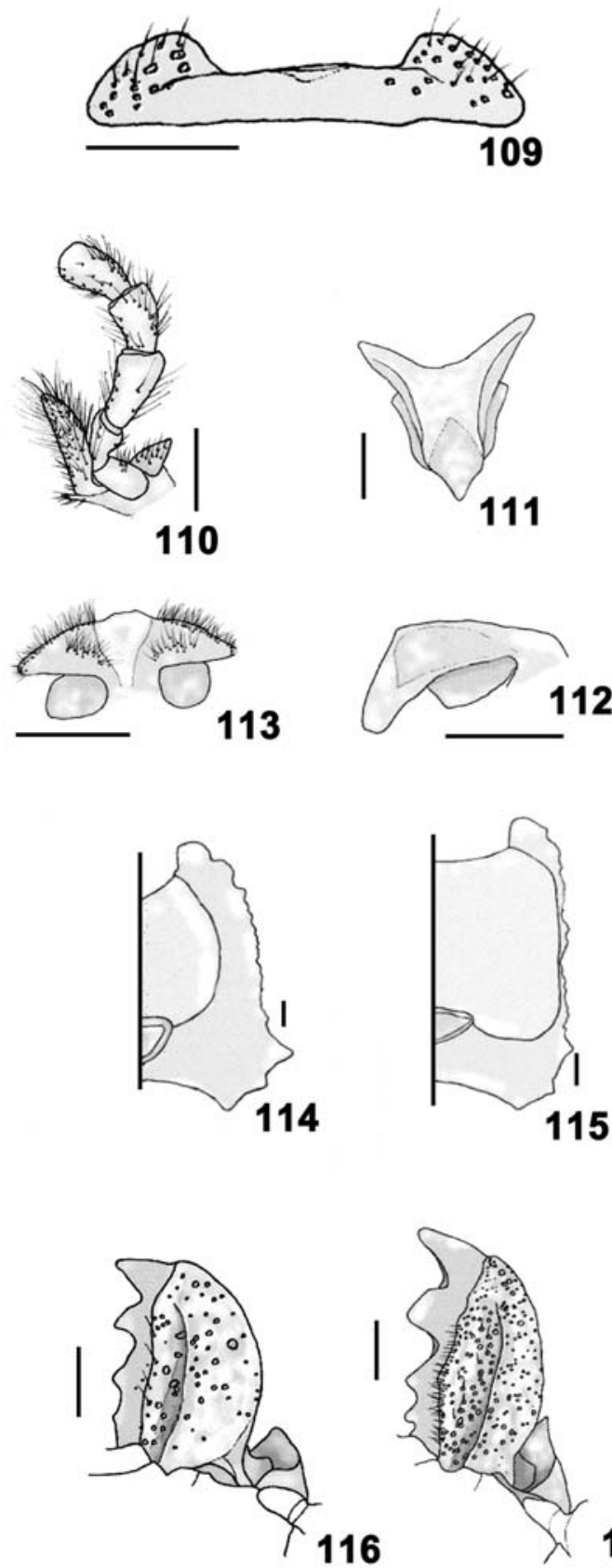

Figs. 107-122. 107-117, Physopleurus maillei. 107, macho, comprimento, 54,5 mm; 108, fêmea, comprimento, 50,0 mm; 109, mento; 110, maxila; 111-113, lígula: 111, face interna; 112, lateral; 113, face externa; 114-115, protórax, ventral: 114, fêmea; 115, macho; 116-117, mandíbula direita: 116, fêmea; 117, macho. Barra $=1 \mathrm{~mm}$. 118-122. Asas membranosas. 118, Physopleurus longiscapus; 119, P. rugosus; 120, P. amazonicus; 121, $P$. seripierriae; 122, $P$. villardi. 
Protórax com comprimento, no centro, cerca de 0,8 vezes a maior largura; bordas laterais fracamente crenadas. Borda anterior do pronoto côncava e sinuosa; cantos anteriores projetados; ângulos das bordas laterais com espinho curto; ângulos posteriores nulos; disco pronotal com calosidades brilhantes e pontos pequenos esparsos; laterais com pontos grandes anastomosados e junto à borda, com faixa estreita mais clara e pontos alongados (aspecto de estrias). Prosterno fortemente intumescido, nítido em vista dorsal, com pontos pequenos e profundos, e pêlos curtos esparsos. Ápice do processo prosternal arredondado. Suturas prosternais (Fig. 115) fortemente arqueadas na base e somente aí visíveis (às vezes nítidas em toda extensão). Proepisternos (Fig. 115) inconspícuos ou fortemente estreitados, representados apenas por uma fina faixa. Metasterno glabro, liso e brilhante no centro, micropontuado e com pilosidade abundante nas laterais e região anterior. Metepisternos com pontuação e pilosidade iguais às do metasterno. Élitros finamente pontuados; ápices elitrais inermes. Asas translúcidas. Fêmures e tíbias inermes. Esporão apical externo das protíbias, curto, voltado para baixo.

Fêmea (Fig. 108). Mandíbulas (Fig. 116) mais curtas; dente das margens internas, junto ao dente apical, aguçados. Escapo menor (apenas ultrapassa a borda posterior do olho). Prosterno com pontuação anastomosada, mais rasa e concentrada. Suturas prosternais nítidas. Proepisternos (Fig. 114) nítidos em toda extensão. O protórax apresenta variação notável na forma (Fragoso \& MonNÉ, 1995b).

Dimensões, em mm (macho / fêmea). Comprimento total, 54,0-54,5 / 47,3-50,0; protórax: largura anterior, 10,5-11,5 / 9,511,0; largura entre os espinhos dos ângulos das margens

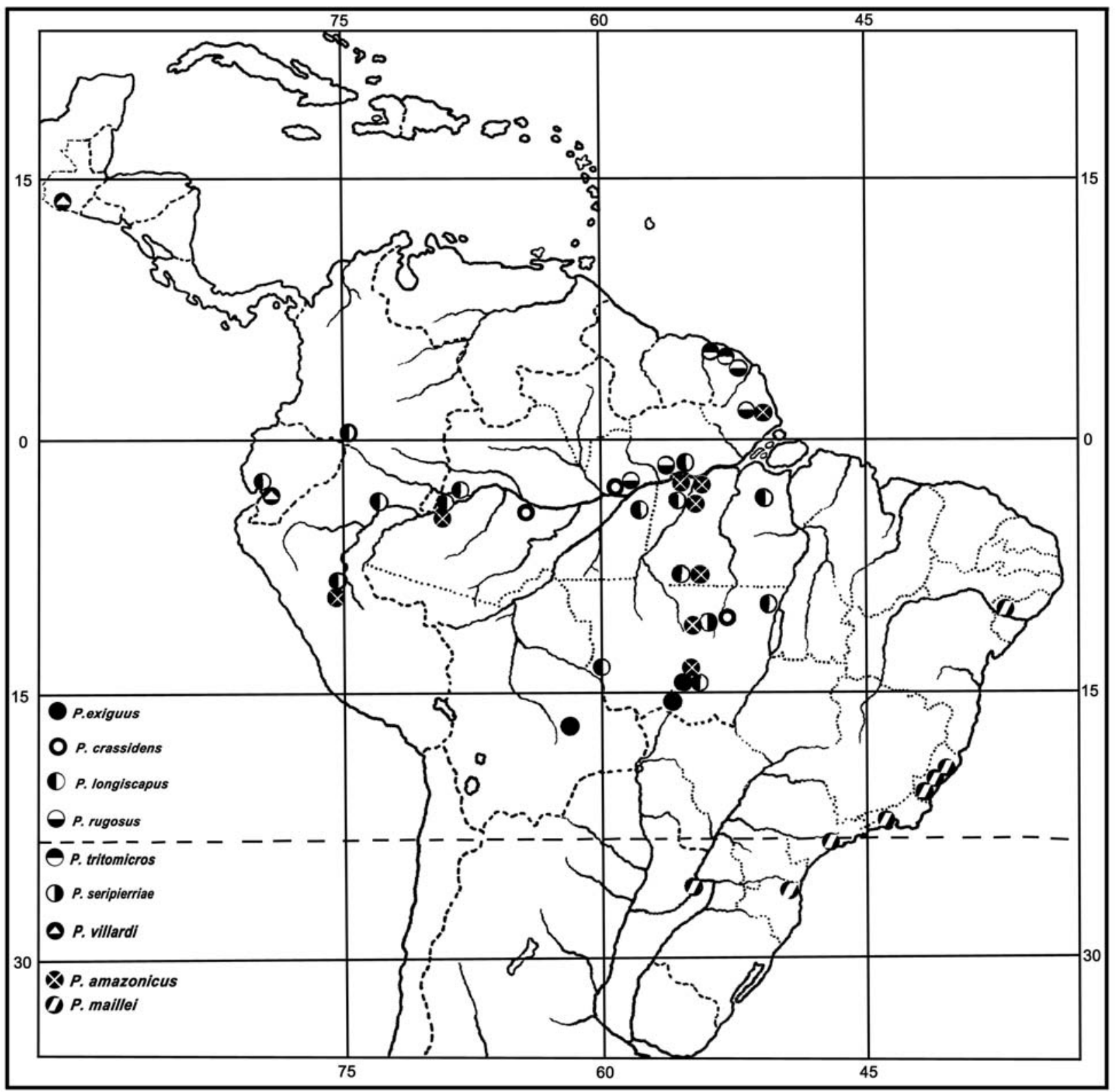

Fig. 123. Ocorrências das espécies de Physopleurus (exceto P. dohrnii). 
laterais, 14,2-14,7 / 13,4-14,6; comprimento do pronoto (centro), 9,5-9,9/8,0-9,5; largura umeral, 14,1-15,0 / 14,0-16,0; comprimento elitral, 33,5-35,2/33,0-36,5.

Tipo, localidade-tipo. Holótipo fêmea, BRASIL, depositado no BMNH (não examinado).

Discussão. LAMEERE (1912) ao referir-se a Basitoxus maillei, disse: "Les mandibules non carénées em dessus distinguent cette espèce de toutes celles du genre Physopleurus" e "les tubercules antennifères sont anguleux". Com relação à primeira afirmativa, o exame de vários exemplares desta espécie mostra que há variação na forma da carena dorsal das mandíbulas, que pode ser muito suave ou relativamente nítida. A segunda afirmativa deixa claro que a espécie possui os tubérculos anteníferos como nas espécies incluídas pelo próprio Lameere no seu grupo "Stenodontes", onde se insere o gênero Physopleurus.

LAMEere (1912) referiu-se a uma fêmea proveniente da Argentina (Tucumán), que acreditava corresponder a $P$. maillei. Examinamos uma fêmea da Argentina (Misiones) que provavelmente, pertence a uma espécie nova, semelhante a $P$. maillei e a $P$. amazonicus. Difere da primeira: escapo mais curto; antenômeros mais grossos; ápice genal menos saliente; pilosidade ventral mais esparsa; esporão tibial externo das protíbias mais saliente. Da segunda difere: curvatura da sutura do prosterno semelhante à de $P$. maillei; pontuação da cabeça mais forte. Optamos por não descrever a espécie até que seja possível obter maior número de exemplares para estudo, uma vez que o exemplar pode ser aberrante.

Material examinado. BRASIL. Alagoas: Delmiro Gouveia, fêmea, 1940, sem nome do coletor (MNRJ). Espirito Santo: Colatina, macho, XI.1970, A. Silva col. (MNRJ); Conduru, fêmea, XII.1940, sem nome do coletor (MNRJ); Linhares, macho, XII.1965, sem nome do coletor, fêmea, X.1969, sem nome do coletor, 2 fêmeas, XI.1969, B. Silva col. (MNRJ); (Parque Sooretama), fêmea, 7.X.1959, D. Zajciw col., fêmea, III.1970, B. Silva col. (MNRJ); Rio Bonito, fêmea, XII.1966, sem nome do coletor (MNRJ); Vargem Alta, fêmea, XI.1940, sem nome do coletor (MNRJ). Rio de Janeiro: Rio de Janeiro (Corcovado), fêmea, 12.I.1954, D. Zajciw col., fêmea, XII.1958, fêmea, 15.XII.1958, fêmea, 30.XII.1958, Alvarenga \& Seabra col., fêmea, 16.I.1961, D. Zajciw col., fêmea, I.1963, fêmea, 8.I.1964, fêmea, XII.1966, fêmea, 25.I.1968, Alvarenga \& Seabra col., fêmea, XII.1968, fêmea, I.1969, S. A. F. col., fêmea, 27.I.1977, Seabra col. (MNRJ); (Floresta da Tijuca), fêmea, II.1938, fêmea, I.1961, Campos Seabra col., fêmea, X.1972, fêmea, XII.1972, fêmea, I.1973, S. A. F. col., fêmea, XII.1976, Seabra col. (MNRJ); (Floresta do Macaco), fêmea, I.1958, fêmea, XII.1958, fêmea, I.1959, Altamiro B. Pereira col. (MNRJ); (Horto Florestal), fêmea, 7.II.1992, C. A. Caetano col. (MNRJ); (Quinta da Boa Vista), fêmea, Newton Santos col. (MNRJ). São Paulo: Cubatão (Parque Municipal do Pereque), fêmea, 12.II.2001, Santos-Silva col. (MZSP). Santa Catarina: Corupá, fêmea, I.1937, A. Maller col., fêmea, II.1943, B. Silva col., fềmea, II.1950, macho, I.1956, A. Maller col., fêmea, I.1969, sem nome do coletor, fêmea, sem data, A. Maller col. (MNRJ). ARGENTINA, Misiones: Iguazú, fêmea, 11.XII.1978, Foerster col. (MZSP).

Agradecimentos. A Gérard L. Tavakilian (MNHN) pelo empréstimo de material para estudo e valiosas informações sobre P. crassidens. Ao Dr. Steve W. Lingafelter (USNM) por tentar localizar o holótipo de Aplagiognathus guatemalensis. Ao Dr. Bert Viklund (NHRS) pelas fotografias de P. dohrnii. Ao Dr. Miguel A. Monné (MNRJ) e à Dra.
Maria Helena Galileo (MCNZ) pelo empréstimo de material para estudo. À Dra. Dilma Solange Napp (DZUP) pelo empréstimo dos diapositivos dos tipos.

\section{REFERÊNCIAS}

Audinet-Serville, J. G. 1832. Nouvelle classification de la famille des Longicornes. Annales de la Société Entomologique de France (1) 1: 118-201.

Bates, H. W. 1869. Constributions to an Insect Fauna of the Amazon Valley (Coleoptera, Prionides). The Transactions of the Entomological Society of London 1869: 37-58.

BlackWELder, R. E. 1946. Checklist of the coleopterous insects of Mexico, Central America, the West Indies and South America. Part 4. Bulletin of the United States National Museum 185: 551763.

Campos, F. 1939. Entomoteratologia. Nuevas anormalidades advertidas em el Coleoptero Stenodontes Villardi Lameer. Revista Chilena de Historia Natural 43: 26-29.

Casey, T. L. 1912. Studies in the Longicornia of North America. Memoirs on the Coleoptera 3: $215-376$.

ChemsaK, J. A. 1996. Illustrated Revision of the Cerambycidae of North America. Parandrinae, Spondylidinae, Aseminae, Prioninae. v I., Burbank, Wolfsgarden Books, 149 p, 10 est.

Chemsak, J. A.; E. G. Linsley \& F. A. Noguera, 1992. Listados Faunisticos de Mexico II. Los Cerambycidae y Disteniidae de Norteamerica, Centroamerica y las Indias Occidentales (Coleoptera). México, Universidad Nacional Autónoma de México, Instituto de Biologia, $204 \mathrm{p}$.

Damoiseau, R. \& J. CoOls. 1987. Liste du materiel typique conservé dans les collections entomologiques de l'Institut royal des Sciences naturelles de Belgique. Coleoptera, Cerambycoidea, Cerambycidae: Aseminae, Cerambycinae, Disteniinae, Lepturinae, Parandrinae, Prioninae et Spondylinae. Documents de travail 42: 1-39.

Fragoso, S. A. \& Monné, M. A. 1995a. Notes on Macrotomini (Coleoptera, Cerambycidae, Prioninae). Revista Brasileira de Biologia 55(2): 215-225.

Fragoso, S. A. \& Monné, M. A. 1995b. Second note on Macrotomini (Coleoptera, Cerambycidae, Prioninae). Revista Brasileira de Biologia 55(4): 715-726.

Gahan, C. J. 1894. Descriptions of some new species of Prionidae. Annals and Magazine of Natural History (6) 14: 221-227.

Gahan, C. J. 1906. The fauna of British India including Ceylon and Burma. Coleoptera. Cerambycidae. London, Taylor \& Francis, v. 1: xviii +329 p.

Gemminger, M. \& E. Harold, 1872. Catalogus Coleopterorum hucusque descriptorum synonymicus et systematicus. Monachii, 9: 2669-2988.

Lacordaire, J. T. 1869. Histoire Naturelle des Insectes. Genera des Coléoptères. Paris, Libr. Encycl. de Roret, 8: 1-552.

Lameere, A. 1902. Revision des Prionides (Quatrième mémoire Sténodontines) Annalles de la Société Entomologique de Belgique 9: 63-110.

Lameere, A. 1903. Révision des Prionides (Sixième mémoire - Basitoxus). Annales de la Société Entomologique de Belgique 47: 213 224.

LAMEERE, A. 1912. Révision des prionides (Vingt-deuxième mémoire Addenda et Corrigenda). Mémoires de la Société Entomologique de Belgique 21: 113-188.

Lameere, A. 1913. Coleopterorum Catalogus, pars. 52, Cerambycidae. Prioninae. Berlin, W. Junk, 108 p.

Lameere, A. 1919. Genera Insectorum, Coleoptera, Fam. Cerambycidae, Subfam. Prioninae. Bruxelles, P. Wytsman, v. 172, 189 p.

LinSLEY, E. G. 1957. Descriptive and synonymical notes on some North Amercian Cerambycidae (Col.). American Museum Novitates 1828: $1-21$.

Linsley, E. G. 1962. The Cerambycidae of North America. Part II 
Taxonomy and classification of the Parandrinae, Prioninae, Spondylinae and Aseminae. University of California Publications in Entomology 19: 1-102.

Maes, J. M.; A. Allen; M. A. Monné \& F. T. Hovore. 1994. Catálogo de los Cerambycidae (Coleoptera) de Nicaragua. Revista Nicaragüense de Entomologia 27: 1-58.

Monné, M. A. 1995. Catalogue of the Cerambycidae (Coleoptera) of the Western Hemisphere. Part XXII. São Paulo, Sociedade Brasileira de Entomologia. $115 \mathrm{p}$.

Monné, M. A. \& E. F. Giesbert. 1994. Checklist of the Cerambycidae and Disteniidae (Coleoptera) of the Western Hemisphere. Burbank, Wolfsgarden Books, $410 \mathrm{p}$.

Rosales, C. J. 1966. Contribucion al conocimiento de los Prioninae (Coleóptera: Cerambycidae) de Venezuela. Revista de la Faucltad de Agronomia de la Universidad Central de Venezuela 11: 1 $-237,11$ est.

Tavakilian, G. L. 1996. In: V. Hequet. Longicornes de Guyane. Cayenne,
Silvolab, sem paginação, 19 est.

WeIDNER, H. 1976. Die Entomologischen Sammlungen des Zoologischen Instituts und Zoologischen Musuems der Universität Hamburg, IX Teil, Insecta VI, (Coleoptera). Mitteilungen aus dem Hamburgischen Zoologischen Museum und Institut 73: 87 264.

WeidNER, H. 1979. Die Entomologischen Sammlungen des Zoologischen Instituts und Zoologischen Musuems der Universität Hamburg, Nachtrag zum IX. Teil, Insecta VI, (Coleoptera). Mitteilungen aus dem Hamburgischen Zoologischen Museum und Institut 76: $395-468$.

Wendt, H. 1984. Die Cerambyciden - Typen (Coleoptera, Phytophaga) des Zoologisches Museums Berlin. Teil I: Unterfamilie Prioninae. Mitteilungen aus dem Zoologischen Museum in Berlin 2: 327-342.

ZAJCIW, D. 1960. Longicórneos novos para a fauna do Brasil (Col. Cerambycidae). II. Revista Brasleira de Entomologia 9: 69-79. 